\title{
EVOLUÇÃO URBANA E DA COBERTURA VEGETAL DE PIRACICABA - SP (1940 - 2000)
}

\section{Francisca Pinheiro da Silveira Costa}

\author{
Dissertação apresentada à Escola Superior de \\ Agricultura "Luiz de Queiroz”, Universidade de \\ São Paulo, para obtenção do título de Mestre em \\ Ecologia de Agroecossistemas.
}

\author{
P I R A C I C A B A \\ Estado de São Paulo - Brasil \\ Maio - 2004
}




\title{
EVOLUÇÃO URBANA E DA COBERTURA VEGETAL DE PIRACICABA - SP (1940 - 2000)
}

\author{
Francisca Pinheiro da Silveira Costa \\ Geógrafa
}

Orientador: Prof. Dr. GERD SPAROVEK

\begin{abstract}
Dissertação apresentada à Escola Superior de Agricultura "Luiz de Queiroz”, Universidade de São Paulo, para obtenção do título de Mestre em Ecologia de Agroecossistemas.
\end{abstract}

\author{
P I R A C I C A B A \\ Estado de São Paulo - Brasil \\ Maio - 2004
}




\section{Dados Internacionais de Catalogação na Publicação (CIP) DIVISÃO DE BIBLIOTECA E DOCUMENTAÇÃO - ESALQ/USP}

\section{Costa, Francisca Pinheiro da Silveira}

Evolução urbana e da cobertura vegetal de Piracicaba - SP (1940-2000) / Francisca Pinheiro da Silveira Costa. - - Piracicaba, 2004.

82 p. : il.

Dissertação (mestrado) - - Escola Superior de Agricultura Luiz de Queiroz, 2004.

Bibliografia.

1. Arborização 2. Cobertura vegetal 3. Planejamento territorial urbano 4. Sistemas c Informações Geográficas 5. Zona urbana I. Título

CDD 715.2 


\section{DEDICATÓRIA}

Dedico esta Dissertação ao meu querido esposo Nevton Pereira da Costa, pelo carinho, incentivo e apoio durante este período de crescimento intelectual e ao meu filho Victor Pinheiro Costa, que tem sido paciente com a Mamãe nas horas de trabalho e porque ele tem sido uma fonte inspiradora e de muita alegria em minha vida. 


\section{AGRADECIMENTOS}

\section{Agradeço:}

- A Deus por ser o Autor da minha vida e por conceder-me todas as bênçãos e as condições necessárias para o desenvolvimento deste trabalho.

- À Escola Superior de Agricultura “Luiz de Queiroz”, que possibilitou a minha aprendizagem no curso de mestrado em Ecologia de Agroecossistemas Interunidades.

- Ao Prof. Dr. Gerd Sparovek, pela orientação e dedicação nas leituras e correções.

- À amiga Lúcia Mendes, que pacientemente me auxiliou nos processos de geoprocessamento e nos momentos de dúvidas.

- Aos colegas da salinha da Esalq, especialmente ao Beto e Amália, que me auxiliaram durante este período de trabalho. 


\section{SUMÁRIO}

Página

LISTA DE FIGURAS.............................................................................. viii

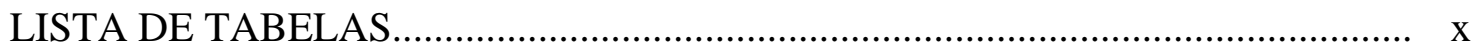

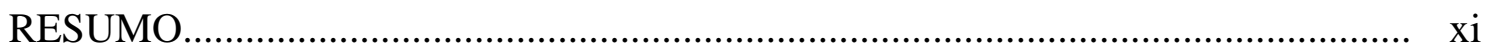

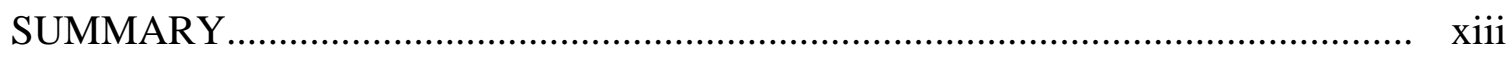

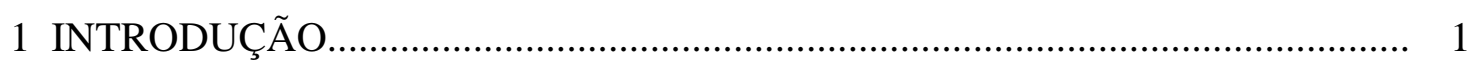

1.1 Considerações iniciais............................................................................. 1

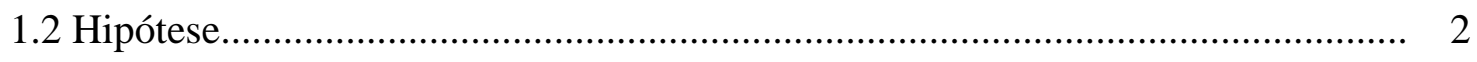

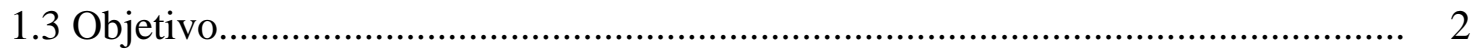

2 REVISÃO DE LITERATURA................................................................. 3

2.1 Importância ambiental no contexto urbano.................................................... 3

2.2 Trabalhos sobre a importãncia ambiental urbana........................................... 5

2.3 Terminologias correlatas ao ambiente urbano................................................ 7

2.4 Planejamentos urbanos: a importãncia do verde............................................ 8

2.5 Periurbano: definindo vetores de crescimentos............................................. 9

2.6 Crescer com qualidade: leis ambientais..................................................... 11

2.7 Síntese da revisão bibliográfica..................................................................... 14

3 MATERIAL E MÉTODO.......................................................................... 16

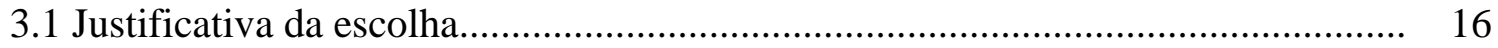

3.2 Características gerais do município de Piracicaba........................................... 16

3.2.1 Localização e demografia........................................................................... 16

3.2.2 Aspectos da geografia física do município................................................... 17

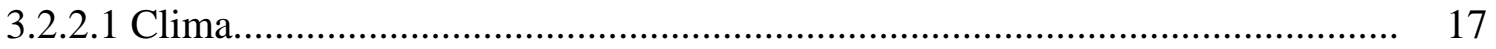


3.2.2.2 Geomorfologia e solos

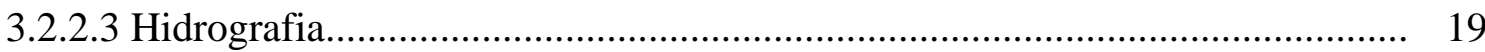

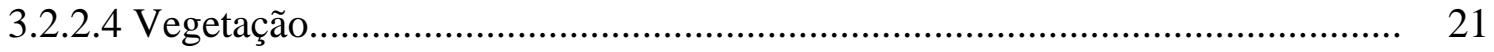

3.2.2.5 Área urbana de Piracicaba....................................................................... 21

3.3 Síntese da caracterizção da áreas em estudo.................................................. 22

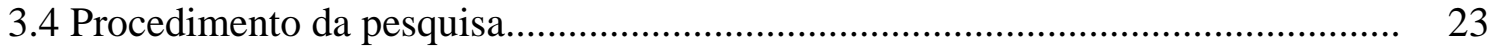

3.4.1 Levantamento das fotografias aéreas........................................................... 23

3.4.2 Georreferenciamento e fotointerpretação..................................................... 25

3.4.3 Critérios utilizados na área de estudo........................................................ 27

3.4.4 Levantamento bibliográfico.................................................................. 27

3.4.5 Discussão e conclusão............................................................................. 27

3.5 Síntese do material e método......................................................................... 28

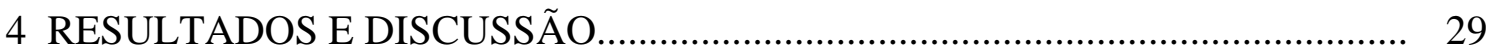

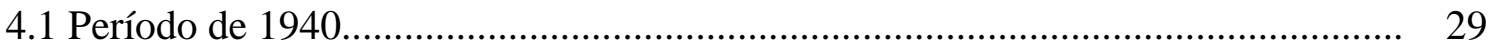

4.2 Período de 1962 ............................................................................................. 34

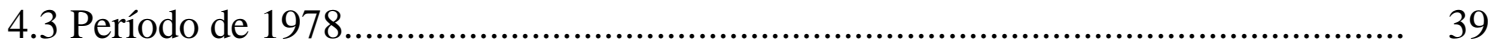

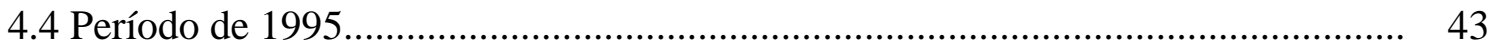

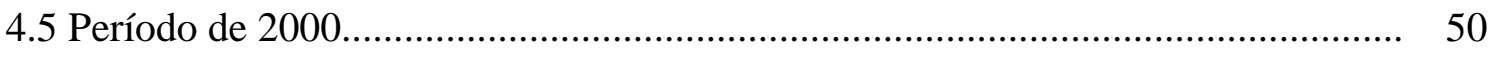

4.6 Análise cartográfica do período de 1940 a 2000............................................... 54

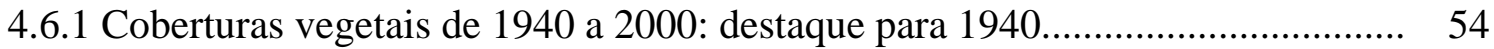

4.6.2 Coberturas vegetais de 1940 a 2000: destaque para 2000.............................. 55

4.6.3 Evolução da área urbana consolidada de Piracicaba entre 1940 a 2000............ 57

4.6.4 Evolução do perímetro urbano e da cobertura vegetal de piracicaba entre 1940

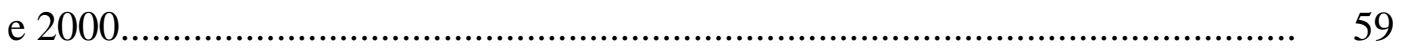

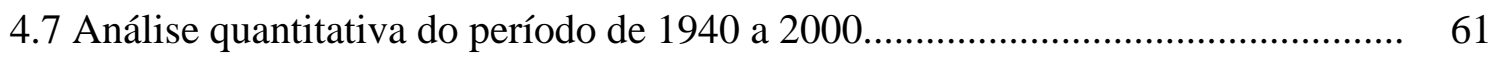

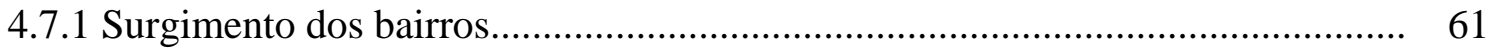

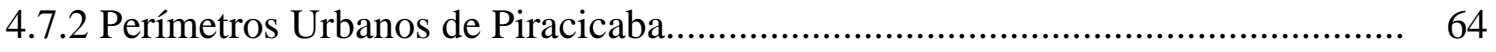

4.7.3 Cobertura vegetal por habitante............................................................... 65

4.7.4 Áreas da cobertura vegetal em relação aos perímetros urbanos......................... 67 
4.8 Características das três áreas de cobertura vegetal que mais se destacaram em

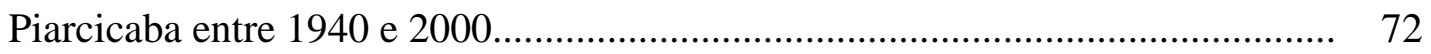

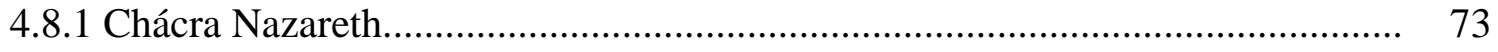

4.8.2 Parque do Mirante/Engenho Central............................................................. 73

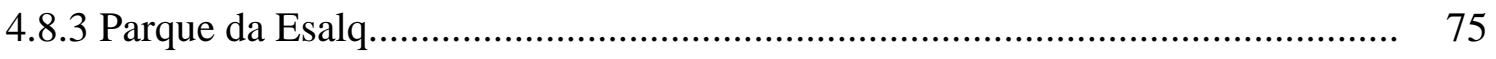

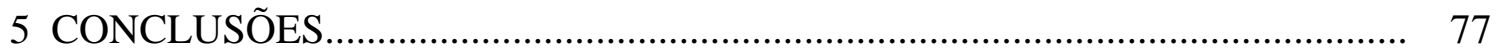

REFERÊNCIAS BIBLIOGRÁFICAS............................................................ 78 


\section{LISTA DE FIGURAS}

Página

1 Localização de Piracicaba no Estado de São Paulo..................................... 17

2 Mapa da hidrografia do Município de Piracicaba...................................... 20

3 Mapa do Zoneamento Urbano de Piracicaba............................................. 22

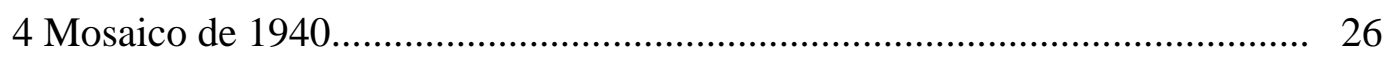

5 Perímetro Urbano e Áreas de Cobertura Vegetal de 1940............................ 30

6 Perímetros Urbanos de 1940 a 2000 e Áreas de Cobertura Vegetal de 194.. 33

7 Perímetro Urbano e Áreas de Cobertura Vegetal de 1962............................ 35

8 Perímetros Urbanos de 1940 e 1962 e Áreas de Cobertura Vegetal de 1962. 38

9 Perímetro Urbano e Áreas de Cobertura Vegetal de 1978............................ 40

10 Perímetros Urbanos de 1940 a 1978 e Áreas de Cobertura Vegetal de 1978.

11 Perímetro Urbano e Cobertura Vegetal de 1995. 47

12 Perímetros Urbanos de 1940 a 1995 e Áreas de Cobertura Vegetal de 1995.

13 Perímetro Urbano e Áreas de Cobertura Vegetal de 2000........................... 51

14 Perímetros Urbanos de 19940 a 2000 e Áreas de Cobertura Vegetal de 2000. 53

15 Áreas Verdes de 1940 a 2000 e Área Urbana de 2000................................. 54

16 Áreas Verdes de 2000 a 1940 e Perímetro Urbano de 2000........................... 56 
17 Evolução urbana de Piracicaba entre 1940 a 2000...................................... 58

18 Evolução do perímetro urbano e da cobertura vegetal de Piracicaba

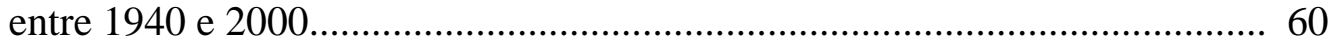

19 Cobertura vegetal urbana por habitante.............................................. 67

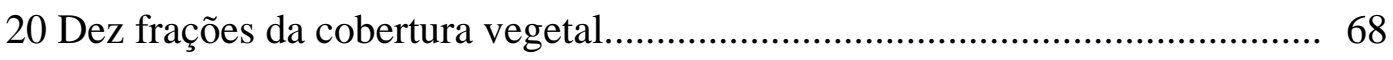

21 Entrada da Chácara Nazareth.................................................................... 73

22 Chácara Nazareth.............................................................................. 73

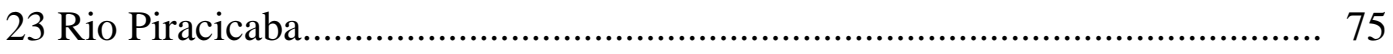

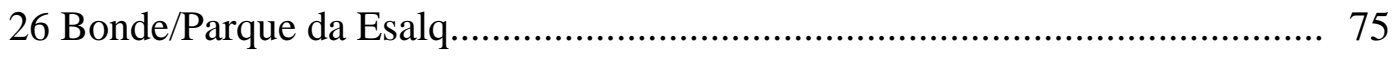




\section{LISTA DE TABELAS}

Página

1 Índice de áreas verdes por habitantes de algumas cidades brasileiras, segundo GUZZO.

2 Área verde de proteção, reserva e recreação de Piracicaba................................. 13

3 Materiais utilizados para a definição do perímetro urbanizado de Piracicaba (SP) entre 1940 a 2000, escala, empresa executora e

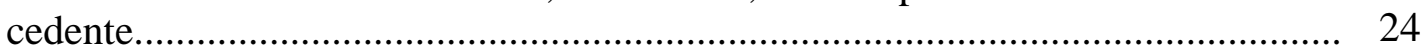

4 Vetores de Expansão Urbanos, propostos pelo Plano Diretor de $1991 \ldots . . . \ldots \ldots . . . . . . . . . .43$

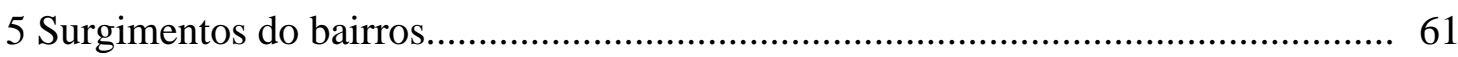

6 Histórico da oficialização dos perímetros urbanos de Piracicaba........................... 64

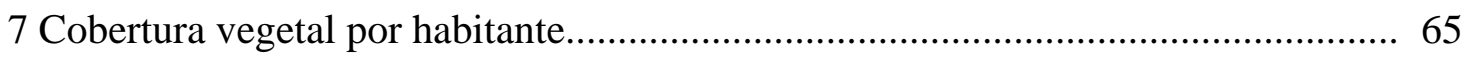

8 Área total da cobertura vegetal urbana em relação ao total da população

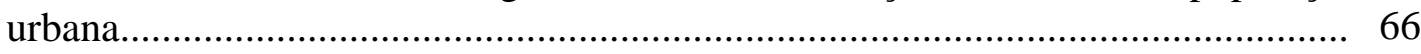

9 Distâncias dos fragmentos da cobertura vegetal em relação ao perímetro

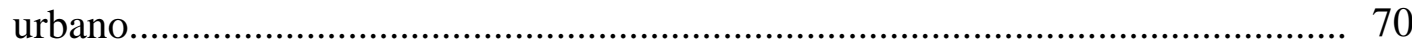




\title{
EVOLUÇÃO URBANA E DA COBERTURA VEGETAL DE PIRACICABA - SP
}

(1940-2000)

\author{
Autora: FRANCISCA PINHEIRO S. COSTA \\ Orientador: Prof.Dr. GERD SPAROVEK
}

\section{RESUMO}

Este trabalho procurou evidenciar os vetores de expansão urbana da cidade de Piracicaba entre os períodos de 1940 e 2000, ressaltando também as áreas de cobertura vegetal que mais sobressaíram durante estes anos. Para realização do trabalho foi feito um levantamento de fotografias aéreas de 1940, 1962, 1978, 1995 e 2000, dividindo em cinco períodos a observação e discussão. As fotografias foram georreferenciadas e convertidas em formato matricial (tif) e as fotointerpretações aconteceram em um Sistema de Informação Geográfica (SIG), utilizando o programa TNT Mips 6.0. As análises levaram aos resultados e à conclusão do trabalho. Em cada período proposto para análise foi realizado uma interação com os aspectos sociais e econômicos que exerceram de alguma forma influência sobre o direcionamento urbano. Também foi possível realizar a integração entre a expansão urbana que ocorreu e as projetadas pelos Planos Diretores da cidade, mas especificamente o Plano Diretor Urbano de 1991. 
As localizações das áreas de cobertura vegetal foram delimitadas em cada período, evidenciando as frações dentro e no entorno (região periurbana) da cidade. Algumas áreas desapareceram e outras surgiram e isso foi mostrado em mapas e tabelas, gerando uma discussão sobre como essas áreas podem exercer papel importante no aspecto ambiental urbano. 


\title{
URBAN EVOLUTION AND OF THE VEGETABLE CONREAGE OF PIRACICABA - SP (1940 - 2000)
}

\author{
Author: FRANCISCA PINHEIRO S. COSTA \\ Adviser: Prof. Dr.GERD SPAROVEK
}

\section{SUMMARY}

This work tried to evidence the vectors of urban expansion of the city of Piracicaba among periods of 1940 and 2000, also stressing the areas of vegetable coverage that excelled most during these years. For the accomplishment of work a rising of areas pictures of 1940 were done, 1962, 1978, 1995 and 2000, dividing into five periods the observations and discussions. The pictures were georreferenciadas and converted in digital format matricial (tif) and fofointerpretations happened in an Information System Geographical TNT Mips 6.0. The analyses carried to the results and conclusion of work. In each proposed period for analysis was accomplished an interaction with the social and economic aspects that exercised somehow influence on the urban direction. It also was possible to accomplish the integration between urban expansion that occurred and the projected by the Flat Directors of the city, but specifically the Flat Urban Director of 1991. The locations of the areas of vegetable coverages were defined in each period, evidencing the fractions inside and in the spill (periurbana region ) of the city. Some areas disappeared and other arose and that was shown in maps and tables, generating a discussion about as these areas can exercise important paper in the urban environmental aspect. 


\section{INTRODUÇÃO}

\subsection{Considerações iniciais}

Tendo como referencial o espaço urbano, a dinâmica da ocupação e da evolução da cidade de Piracicaba, procuramos neste trabalho evidenciar o espaço urbano consolidado e os vetores de expansão, ressaltando importantes frações da cobertura vegetal.

A pesquisa analisou como foi e tem sido o crescimento urbano de Piracicaba e localizou as áreas de cobertura vegetal nos períodos de 1940 a 2000 . Foi possível também fazer uma organização cronológica do surgimento dos bairros à medida que a cidade se expandiu.

O trabalho foi dividido em quatro etapas principais. A primeira constou do levantamento das fotografias áreas de cinco momentos distintos entre 1940 e 2000, que resultou nos anos de 1940, 1962, 1978, 1995 e 2000. Na segunda fase foi realizado o georreferenciamento das fotografias áreas e a fotointerpretação dos mosaicos gerados. A terceira etapa foi direcionada ao levantamento bibliográfico, para suporte teórico que permitisse compreender melhor o universo proposto para estudo. Na quarta fase foi realizada a análise dos resultados observados, tanto em relação aos vetores e direcionamento da expansão urbana, quanto à localização da cobertura vegetal, possibilitando a elaboração da conclusão do trabalho.

Visando compreender a dinâmica entre a área urbana, periurbana, rural e sua integração com o planejamento urbano e ambiental, SIMÕES (1996) propõe uma abordagem metodológica que saliente o "estudo dos processos" que envolve cada fração. Segundo o autor, é necessário, dentre outras linhas de pesquisa, "a implantação de um 
sistema georreferenciado adequado ao planejamento físico-territorial, contribuindo para a integração das variáveis e monitoramento dos processos físicos”. Para uma avaliação global das mudanças ocorridas na ocupação do solo em uma região, num dado período, é muito importante a utilização de imagens aéreas, uma vez que registram fielmente a ocupação do solo num dado momento. A adequabilidade do geoprocessamento aos estudos de expansão urbana para a cidade de Piracicaba já foi realizada por MARTINES (1998), que relacionou os principais eventos históricos ocorridos entre 1822 e 1996.

Este trabalho visou gerar elementos que pudessem auxiliar na compreensão da dinâmica de urbanização, evidenciando os vetores de sua expansão e o recobrimento vegetal do seu entorno, utilizando georreferenciamento em ambiente de Sistema de Informação Geográfica (SIG).

\subsection{Hipótese}

O levantamento histórico permite compreender a interferência da evolução urbana sobre a quantidade, qualidade e distribuição da cobertura vegetal?

\subsection{Objetivo}

O objetivo dessa pesquisa foi evidenciar os vetores de expansão urbana da cidade de Piracicaba, ressaltando a evolução da cobertura vegetal entre os períodos de 1940 a 2000. 


\section{REVISÃO DE LITERATURA}

\subsection{Importância ambiental no contexto urbano}

Desde a realização da Conferência das Nações Unidas sobre o Meio Ambiente, em Estocolmo, Suécia, em 1972, emergiu e fortaleceu-se pela comunidade internacional uma enraizada consciência de que as questões relativas à proteção ambiental diziam respeito não só aos elementos componentes do meio, tomados isoladamente ou em conjunto, mas com particular ênfase na atuação e na finalidade de proteção ao próprio Homem. Na ocasião da ECO-92, realizada no Rio de Janeiro, Brasil, vários pontos de caráter ambiental se tornaram relevantes e a partir de então os órgãos governamentais de planejamento, as instituições de ensino e vários ramos da sociedade procuraram colocar com maior ênfase a preocupação com estas questões, pois são dos recursos ambientais que depende a própria qualidade de vida dos habitantes do planeta. A preocupação com esses temas aflora nos anos 80 , mas se tornam fundamentais a partir dos anos 90.

Um fator relevante na atualidade tem sido a preocupação com a questão ambiental que permeia a qualidade de vida das pessoas e estas estão em maior números nas áreas urbanas, revelando que o ambiente urbano deve ter uma atenção especial.

A principal característica do crescimento populacional tem sido o novo perfil de crescimento no qual a população urbana é cada vez maior que a rural, ou seja, o crescimento populacional passou a ocorrer de forma mais acentuada nas áreas urbanas, com diminuição da população rural, ocasionando um "inchaço” nas cidades, já que a migração do campo para a cidade ocorreu de forma intensa e a população ocupou, de forma desordenada, os territórios urbanizados (DUARTE, 2003). 
Mais recentemente a preocupação ambiental está se direcionando para os centros urbanos, pois o mundo já é caracterizado por áreas de grandes concentrações humanas em locais urbanos. A qualidade de vida urbana principalmente com relação à deterioração de seu entorno mais imediato provocado pelo processo acelerado de urbanização, representa uma das preocupações dos países em desenvolvimento (OREA, 1978).

Nos Estados Unidos pesquisas têm mostrado a mesma preocupação em relação ao ambiente urbano, pois a população urbana está crescendo em todos os ambientes, sejam locais, regionais e globais, ocasionando um choque significativo no ambiente natural, resultando em conseqüências ambientais amplas (DWYER, et al., 2000).

No Brasil, nas últimas décadas, a população urbana tem crescido de forma acentuada. Na região sudeste, esse processo se intensificou a partir da década de 1940 como reflexo do êxodo rural motivado, por um lado, pela ampliação das relações capitalistas no campo, mecanização da agricultura e pela especulação imobiliária e por outro, pelos atrativos das cidades veiculados pela mídia sobre uma população que cada vez mais perdia suas raízes com a terra (SCARLATO,1996). Conforme dados censitários, atualmente, cerca de $81 \%$ da população brasileira está concentrada nas áreas urbanas, sendo que no município de Piracicaba a proporção é de 96,4\% da população nas áreas urbanas e 3,6\% nas áreas rurais, contabilizando 317.374 habitantes na área urbana e 11.784 na área rural, num total de 329.158 habitantes em todo o município (IBGE - 2000).

Os impactos no ambiente onde se instala e se desenvolve uma cidade afetam todos os elementos naturais, sejam eles bióticos ou abióticos. "A paisagem não é uma simples adição de elementos geográficos disparatados” (CAVALHEIRO,1995). É, em uma determinada porção do espaço, o resultado da combinação dinâmica, portanto instável, de elementos físicos, biológicos e antrópicos que, reagindo dialeticamente uns sobre os outros, fazem da paisagem um conjunto único e indissociável, em perpétua evolução (GUZZO-1999). 
A problemática ambiental urbana apresenta-se neste início de século como uma das questões de planejamento das cidades, institucionalizada por meio de movimentos e grandes conferências. Da década de 1970 até nossos dias, observa-se que a trajetória da questão do meio ambiente evoluiu da proteção ambiental para o conceito de desenvolvimento sustentável ou ecodesenvolvimento. Do enfoque aos santuários ecológicos para os problemas ambientais metropolitanos, as cidades passaram de antagônicas ao meio ambiente para objeto de estudos sobre sustentabilidade ambiental. Neste contexto, o uso e ocupação do solo, o planejamento e a gestão urbana figuram como os grandes instrumentos na busca de um equilíbrio sócio-ambiental (MORENO, 2000).

\subsection{Trabalhos sobre a importância ambiental urbana}

Vários trabalhos estão sendo direcionados para entender melhor os ambientes urbanos e como planejar adequadamente seu crescimento, a fim de proporcionar ao homem citadino condições mais favoráveis ao seu bem estar. Como as áreas verdes, espaços livres, verdes urbanos e locais de lazer são lugares que possibilitam ao homem um encontro com a paz e o descanso desejado, estes locais têm se tornado tema de estudos na atualidade.

Entre os mais recentes estudos sobre a importância ambiental urbana e sua contribuição para a qualidade de vida, foi destacado nesta pesquisa o trabalho intitulado "Estudo dos espaços livres de uso público da cidade de Ribeirão Preto/SP, com detalhamento da cobertura vegetal e áreas verdes públicas de dois setores urbanos” do autor GUZZO, 1999. Neste trabalho há uma revisão de outros trabalhos que enfocaram a quantidade e a qualidade da vegetação presente nas cidades e as áreas para o lazer da população, bem como os índices de verde em $\mathrm{m}^{2} / \mathrm{hab}$. Ele enfatizou o ambiente natural e especialmente as áreas verdes dos locais urbanos como sendo espaços primordiais na melhoria da qualidade de vida das populações e comparou algumas cidades brasileiras analisando a questão ambiental de cada uma delas. 
A tabela 1 mostra os índices de áreas verdes em $\mathrm{m}^{2} / \mathrm{hab}$ de várias localidades, apresentadas pelo autor. Apesar de terem sido utilizados métodos diferentes para a obtenção desses dados, ele chegou às seguintes informações:

Tabela 1. Índice de áreas verdes por habitantes de algumas cidades brasileiras, segundo GUZZO

\begin{tabular}{cccc}
\hline NOME DA CIDADE & ESTADO & $\begin{array}{c}\text { ÍNDICE } \\
\mathrm{m}^{2} / \text { hab }\end{array}$ & ANO \\
\hline Ribeirão Preto & SP & 0,7 & 1988 \\
Maringá & PR & 20 & 1990 \\
Bauru & SP & 2,85 & 1990 \\
Porto Alegre & RS & 3,08 & 1990 \\
Curitiba & PR & 50,15 & 1987 \\
Vitória & ES & 82,7 & 1991 \\
Jaboticabal & SP & 5,3 & 1992 \\
Botucatu & SP & 6,23 & 1992 \\
São Carlos & SP & 2,3 & 1994 \\
Piracicaba & SP & 2,2 & 1990
\end{tabular}

Fonte: GUZZO, 1999.

O levantamento da cidade de Piracicaba feito por LIMA (1990) já foi refeito pela prefeitura do município e constatou um índice um pouco melhor em 1994 de $3,2 \mathrm{~m}^{2} / \mathrm{hab}$.

O mais relevante neste trabalho foi o destaque para a importância de se ter nas cidades espaços livres de preferência com a presença de verde para uso da população. "A vegetação existente nas cidades é um importante indicador de qualidade ambiental” (GUZZO, 1999). As áreas verdes urbanas têm um papel fundamental na melhoria da qualidade ambiental pela atenuação da poluição térmica, gasosa, sonora e 
visual, promovendo a melhoria da saúde física e mental da população, além da valorização econômica do entorno, dentre outros benefícios (MILANO, 1992).

Segundo José Afonso da Silva em sua obra "O Direito Ambiental Constitucional”, “a cidade industrial moderna, com seu cotejo de problemas, colocou a exigência de áreas verdes, parques e jardins, como elemento urbanístico, não destinados apenas à ornamentação urbana, mas como uma necessidade higiênica, de recreação e mesmo de defesa e recuperação do meio ambiente em face da degradação de agentes poluidores, e elementos de equilíbrio do meio ambiente urbano, de equilíbrio psicológico, de reconstrução da tranqüilidade, de recomposição do temperamento, desgastados na faina estressante diária. A arborização das vias públicas, além de embelezá-las, é também um fator de atenuação de ruídos, de fixação e retenção do pó, da reoxigenação do ar”.

\subsection{Terminologias correlatas ao ambiente urbano}

Com referência ao termo adequado para ser usado no estudo direcionado sobre o verde urbano e sua função ambiental, foram encontrados alguns autores que cuidadosamente analisaram diversas terminologias e seu emprego. A proposta de conceituação de termos correlatos a espaços livres urbanos de LIMA (1994) define, "Espaço Livre” como sendo um conceito mais abrangente, integrando os demais e contrapondo-se ao espaço construído, em áreas urbanas. “Área Verde” é onde se encontra o predomínio de vegetação arbórea, englobando as praças, os jardins públicos e os parques urbanos. Os canteiros centrais de avenidas e os trevos e rotatórias de vias públicas, que exercem apenas funções estéticas devem, também, conceituar-se como áreas verdes. Entretanto, as árvores que acompanham o leito das vias públicas, não devem ser consideradas como tal, pois as calçadas são impermeabilizadas. "Parque Urbano” é uma área verde, com funções ambientais, estéticas e de lazer, entretanto com uma extensão maior que as praças e jardins públicos. "Praça” é um espaço livre público cuja principal função é o lazer. Pode não ser uma área verde, quando não tem vegetação e encontra-se impermeabilizada. “Arborização Urbana” diz respeito aos elementos 
vegetais de porte arbóreo dentro da cidade. Nesse enfoque, as árvores plantadas em calçadas, fazem parte da arborização urbana, porém, não integram o sistema de áreas verdes. “Área Livre e Área Aberta” são termos que devem ter sua função evitada, pela imprecisão na sua aplicação.

Existe uma séria e ampla discussão sobre o emprego correto de termos ao se referir às áreas verdes em ambiente urbano. Neste trabalho o termo adotado será o de cobertura vegetal, por ser mais abrangente e englobar várias categorias de verdes. Os levantamentos aqui realizados evidenciaram áreas com presença arbórea como matas, reflorestamentos e uso agrícola, mas também delimitou áreas onde a árvore nem sempre estava presente em uma grande quantidade, como por exemplo locais de pastagem.

\subsection{Planejamentos urbanos: a importância do verde}

Para que os espaços livres possam desempenhar satisfatoriamente suas funções, é necessário que sejam abordados de forma integrada no planejamento urbano. Ainda a esse respeito, GUZZO (1993) relata que "o planejamento urbano tem sido realizado considerando critérios sociais, econômicos e culturais, mas muito pouco tem sido feito sob o aspecto ecológico”.

A recente análise do "Processo de urbanização de Piracicaba- Estudos dos Planos Diretores (1971-1991), de Lígia Duarte (2003), demonstrou a necessidade de rever os aspectos ambientais que ganharam ênfase na reformulação de 1991, até porque a temática dos anos 90 foi o mundo voltado para as questões de um crescimento sustentável. Segundo ela, no Plano Diretor dos anos 1990, "quebrou-se a tecnocracia do planejamento urbano que ocorreu nas décadas anteriores a Constituição de 1988 e o Movimento da Reforma Urbana influenciaram as mudanças do planejamento urbano. A abordagem da qualidade ambiental que ganhou importância a partir do conceito de Desenvolvimento Sustentável, que teve seu início na discussão internacional sobre meio ambiente através do documento do Clube de Roma em 1971 e seu ápice na Conferência do Rio de Janeiro em 1992 veio a influenciar o Planejamento Urbano da década de 1990. Assim, o meio ambiente se impôs como parâmetro de qualidade de vida, aparecendo 
como fator importante no novo Plano Diretor Urbano que foi desenvolvido para Piracicaba”.

A própria Constituição Federal de 1988 estabeleceu a importância dos Planos Diretores para o melhor direcionamento do crescimento urbano e ressalta o tema ambiental como fator especial dentro desse crescimento, "O Plano Diretor é um instrumento já previsto pela Constituição para a definição da função social da cidade e propriedade de sua localização, para quem a função social da cidade estará sendo atendida de forma plena quando forem reduzidas as desigualdades sociais, e promovidas à justiça e a qualidade de vida urbana” (SOMEKH, 1997).

\subsection{Periurbano: definindo vetores de crescimentos}

Além da temática sobre a necessidade de verde na área urbana, é necessário ressaltar o grau de importância de se conhecer o entorno dos perímetros urbanos, para que o direcionamento através de planos e leis sejam corretos em relação ao meio ambiente natural pré-existente em vários locais. No entanto, o termo periurbano, também é passível de controvérsias e para isso procuramos conceituá-lo segundo CASTELL (1973). Para ele, o periurbano é uma interface que integra o urbano e o rural, sendo que nessa área a relação urbana/rural é evidenciada pela a proximidade com que se processa os serviços e há uma estreita ligação até mesmo viária entre a área rural e urbana. As cidades são os centros religiosos, administrativos e políticos, expressão espacial de uma complexidade social determinada pelo processo de apropriação e de reinvestimento do produto do trabalho. Trata-se de um novo sistema de organização social, mas que não é separado do rural, nem posterior a ele, porque eles são estreitamente ligados no seio do processo de produção de formas sociais, mesmo se, do ponto de vista dessas formas, se esteja em presença de duas situações diferentes (Castells, 1973).

"Essa dicotomia rural/urbano deixa de existir no momento em que práticas antes restritas ao meio urbano são observadas também nos espaços rurais e, por sua vez, os espaços urbanos se expressam como uma extensão do rural, consolidando um 
continuum em que não se observa a distinção entre um espaço e outro. De outro lado, do ponto de vista das relações sociais, não é somente no ambiente urbano que se desenvolvem práticas em que predominam as características das relações das sociedades urbano-industriais, mas elas também são observadas em áreas destinadas à produção agrícola. Economia, sociedade e ecologia são vistas como subsistemas da totalidade complexa, constituindo uma identidade integrada e organizada, cada qual definindo os limites e os condicionantes das outras” (BACELAR - BEZERRA, 1999).

Os entornos urbanos são as áreas que mais rapidamente serão transformadas pelo processo evolutivo do crescente urbanismo emergente. Nelas se estabelecem os novos loteamentos e se visualizam os espaços vazios. Para um crescimento adequado, com direcionamento correto e principalmente uma qualidade de vida satisfatória, a região periurbana deve fazer parte dos estudos relativos ao crescimento urbano (KUBRUSLY, 2000).

A complexidade desse ambiente de transição urbano-rural intensificou-se quando, a partir de meados dos anos 80, houve uma crescente urbanização do meio rural acarretando uma “inversão a favor das ocupações não-agrícolas, em detrimento das agrícolas, culminando com a maior ocupação dos residentes rurais nos mais diversos ramos da atividade econômica” (BALSADI, 2001). Configurou-se, então, o "novo rural brasileiro" ou "rurbano", onde a delimitação entre o rural e o urbano é cada vez mais tênue. “Pode-se dizer que o rural hoje só pode ser entendido como um 'continuum' do urbano do ponto de vista espacial e do ponto de vista da organização da atividade econômica. As cidades não podem ser identificadas apenas com a atividade industrial, nem os campos com a agricultura e pecuária” (GRAZIANO DA SILVA, 1997).

No âmbito das ciências naturais e sociais, sabe-se que "a conversão de espaços naturais pela expansão urbana vem se mostrando como um processo irreversível em praticamente todos os países” (SIMÕES, 1996). A pesquisa científica sobre as interrelações entre sociedade e ambiente encontra-se em rápida evolução em todo o mundo e juntamente com esta evolução se percebe a contestação social frente à situação emergencial da degradação dos recursos naturais e do desenvolvimento predatório. É, 
portanto, de certa forma óbvio que a zona de transição urbano-rural, chamada atualmente de ambiente periurbano (KUBRUSLY, 2000), constitua o ponto nevrálgico do processo de transformação cultural e ambiental, para onde convergem pressão demográfica e os diversos conflitos e interesses econômicos a ela ligados.

Conhecer a cobertura vegetal que precederam a chegada dos equipamentos, dos edifícios, do mobiliário, das vias públicas, torna-se de grande valor para efeitos benéficos e são essenciais à qualidade de vida urbana da futura cidade que se instalará nestes locais (MILANO, 1992). As áreas do entorno que ainda evidenciam cobertura vegetal natural poderão se tornar áreas verdes, espaços livres, jardins, etc, que exercerão importantes funções ambientais dentro da área urbana.

\subsection{Crescer com qualidade: leis ambientais}

Em razão da sua importância, a vegetação é tema de destaque no ordenamento jurídico brasileiro, em todas as esferas políticas, destacando-se as Constituições Federal, Estadual e Municipal, Código florestal, Lei da Política Nacional do Meio Ambiente, dentre outras.

O Estatuto da Cidade é um exemplo da clara necessidade de atentar para o ambiente urbano através de direcionamento adequado. A Constituição Federal no art. 225, relata que, "todos têm direito ao meio ambiente ecologicamente equilibrado, bem de uso comum do povo e essencial à sadia qualidade de vida, impondo-se ao Poder Público e à coletividade o dever de defendê-lo para as presentes e futuras gerações” (título VIII, capítulo VI).

Para um planejamento dinâmico e com direcionamento correto se faz necessário uma harmonia entre as leis que traçam metas a serem seguidas e desenvolvidas. Em relação à questão ambiental urbana pouco se tem, com clareza nas leis nacionais, até porque é um tema recente e que certamente logo terá leis específicas a seu respeito em todos os departamentos ambientais. Mesmo assim, foi organizado um caminho que visualize as leis ambientais. Essa análise passará pelo Código Florestal, 
Leis Federais, Estaduais e Municipais, Leis Complementares, Planos Diretor Urbanos, Plano Diretor Rural e as propostas da Agenda 2010 para o município de Piracicaba.

Até 1987, o Governo Federal era a única esfera pública autorizada a legislar quanto aos recursos florestais. Isto levou ao estabelecimento de normas nacionais visando disciplinar o desmatamento, não se atendo às peculiaridades e às necessidades de cunho regional. Porém, os mecanismos de comando e controle criados não evitaram que o processo de desmatamento avançasse nos diversos Estados brasileiros.

Diante desse problema, a Constituição Federal, promulgada em 5 de outubro de 1988, engajou os governos estaduais e municipais na proteção dos recursos florestais. Pelo inciso VII do Artigo 23 daquela Constituição, passou a ser de competência comum da União, dos Estados, do Distrito Federal e dos Municípios a preservação das florestas, da fauna e da flora. A União, os Estados e o Distrito Federal podem legislar, concorrentemente, sobre as florestas, a caça, a pesca, a fauna, a conservação da natureza, a defesa do solo e dos recursos naturais, sobre a proteção do meio ambiente e sobre o controle da poluição. A competência da União é estabelecer normas gerais, suplementadas pelos Estados. Estes não podem criar normas que sejam contrárias às estabelecidas pela União (Artigo 24 da Constituição Federal).

Após a promulgação da Constituição Federal, os Artigos elaboraram, em 1989, as Constituições Estaduais. A partir de então, diversos Estados passaram a discutir leis referentes aos recursos florestais e a implementá-las, intensificando a execução de políticas estaduais de controle do desmatamento e de incentivo ao reflorestamento.

Anteriormente à Constituição Federal de 1988, no Estado de São Paulo, a proteção das áreas com florestas nativas e a implantação de novas reservas de essências florestais nativas ou exóticas eram funções do Serviço Florestal do Estado de São Paulo. Posteriormente, esse Serviço Florestal foi transformado no Instituto Florestal do Estado de São Paulo, que herdou as áreas de reservas e hortos florestais estudais. Contudo, as atividades de licenciamentos e fiscalização ambiental são de responsabilidade do 
Departamento Estadual de Proteção de Recursos Naturais (DEPRN), que possui estrutura paralela ao IBAMA no Estado de São Paulo (BACHA, 1998).

Em se tratando, mais especificamente do ambiente urbano, José Afonso da Silva, relata a parte da Constituição que regulamenta os parques públicos: "É no art.5” do Código Florestal (Lei 4.771/65) que se encontra o fundamento legal para a criação dos Parques Públicos - Nacionais, Estaduais e Municipais com a finalidade de resguardar atributos excepcionais da natureza, conciliando a proteção integral da flora, da fauna e das belezas naturais, com a utilização para objetivos educacionais, recreativos e científicos”.

Segundo Lígia Duarte (2003), o Plano Diretor Urbano de Piracicaba (1991) evidenciou as áreas verdes de proteção, reserva e recreação, prevendo 834ha para as faixas ao longo dos ribeirões (40m de cada lado) e do rio Piracicaba (100m de cada lado). A tabela 2 organizou a classificação dessas áreas.

Tabela 2. Área verde de proteção, reserva e recreação de Piracicaba

CATEGORIA

\begin{tabular}{cc} 
& ha \\
Matas & 476 \\
Centros de recreação & 235,62 \\
Áreas para prática de artes jovens & 52,35 \\
Parques e jardins locais & 380,52 \\
\hline
\end{tabular}

O Plano cita o Código Florestal (Lei $\mathrm{n}^{\circ}$ 4771, de 1972), adotando-o para a proteção das áreas de preservação do município e incluindo também as áreas de interesse paisagístico. A justificativa era que essas áreas teriam a função de atenuar a poluição, bem como atrair visitantes, não apenas das cidades próximas como de outras regiões. 
A Lei Orgânica do Município estabelece que Piracicaba deve oferecer 10 $\mathrm{m}^{2} /$ hab de área verde, mas se verifica que as áreas verdes são insuficientes e que, de maneira geral, as áreas implantadas para o lazer da comunidade estão irregularmente distribuídas, sendo que o último índice de área verde por habitante realizado em 1994, pelo departamento de planejamento ambiental da prefeitura foi de $3,2 \mathrm{~m}^{2} / \mathrm{hab}$, bem aquém do almejado pelo Plano Diretor de 1991. Atualmente o Plano Diretor está sendo reformulado e um dos aspectos mais relevantes para melhoria é o tema voltado ao ambiente natural urbano.

$\mathrm{Na}$ agenda 2010, que foi elaborada para direcionar o crescimento e desenvolvimento de Piracicaba dentro dos moldes ecologicamente sustentável, estabelecidos na ocasião da ECO-92, ficou clara a real necessidade de trabalhos na cidade que diagnosticasse e criasse soluções viáveis para o aspecto ambiental urbano, mesmo porque, a cidade de Piracicaba traz na sua história um importante visor natural, cantado em seu hino e vivenciado por seu povo, amantes do seu famoso rio.

No capítulo “A dinâmica ambiental” da Agenda 2010, há um relato de que as áreas verdes do município são insuficientes sendo que, a área central concentra as praças mais antigas (os parques do Mirante e da Rua do Porto) e nas áreas periféricas da cidade nunca houve preocupação com a cobertura vegetal e, mais especificamente com a implantação de áreas de lazer. As áreas urbanas situadas ás margens dos rios e ribeirões não apenas se encontram desprotegidas de vegetação nativa como também apresentam alto índice de degradação, por causa da deposição de lixo e da ocupação irregular. Essa situação abre possibilidade para que a política ambiental crie nestes locais áreas de lazer ou áreas verdes (APPs) recompondo as matas ciliares (p.43).

\subsection{Síntese da revisão bibliográfica}

A revisão bibliográfica procurou desenvolver temas relativos ao problema ambiental urbano, mais especificamente em relação ao verde e suas ações benéficas, pois esta tem sido uma preocupação mundial na atualidade. Cada vez mais temas estão se direcionando para a melhoria da vida no planeta e como proporcionar às gerações 
futuras qualidades naturais que até mesmo no presente já se mostram escassas. Em se tratando de vida diária, o tema ambiente urbano, tem sido foco para muitos estudos, pois o dia-a-dia da maioria dos Homens tem se processado dentro das cidades. Os vários autores aqui apresentados mostraram que as cidades são carentes de projetos ambientais para melhorar as condições de vida e amenizar problemas que acabam por afetar a qualidade dos seres humanos que nelas vivem.

Outro enfoque da revisão foi quanto ao crescimento urbano e como as áreas do entorno, conhecias como áreas periurbanas são importantes para análises, pois elas se tornarão em um curto espaço de tempo as novas áreas urbanas. 


\section{MATERIAL E MÉTODO}

\subsection{Justificativa da escolha}

Para o desenvolvimento deste trabalho foi escolhido o município de Piracicaba, por ser um pólo dentro de uma bacia que abrange uma área de $12.400 \mathrm{~km}^{2}$, 50 municípios paulistas e 8\% da população do Estado, sendo, depois de Campinas, a cidade mais populosa dessa bacia. Sua importância regional como “metrópole” que exerce atração populacional sobre os demais municípios foi salientada já em 1958 pela clássica tese “A Zona de Piracicaba” de Heloisa Barthelmess (BARTHELMESS, 1958) e pela própria geografia industrial, como exemplo de interação entre a indústria e a agricultura (SAMPAIO, 1973) entre outras tantas teses e livros que mostram o pólo urbano regional de Piracicaba.

Conclui-se, portanto, que Piracicaba constitui um fundamental exemplo de crescimento urbano dentro do Estado de São Paulo, e ainda carente de estudos sobre sua dinâmica evolutiva de urbanização e impactos nas suas áreas periféricas incorporadas à malha urbana.

\subsection{Características gerais do município de Piracicaba}

\subsubsection{Localização e demografia}

O município de Piracicaba situa-se entre as coordenadas geográficas de 2242’30”S e 47³8’01”W, com uma altitude média de 554m, temperatura máxima de $37,5^{\circ} \mathrm{C}$ e mínima de $18,0^{\circ} \mathrm{C}$ e uma precipitação pluviométrica de $1.070,6 \mathrm{~mm}$. A área total do município é de 1.312,30 $\mathrm{km}^{2}$, sendo a área urbana, entre cidade e distritos de 
$158,06 \mathrm{~km}^{2}$ e a área rural de $1.154,24 \mathrm{~km}^{2}$. A população total é de 329.000 habitantes (IBGE - 2000).

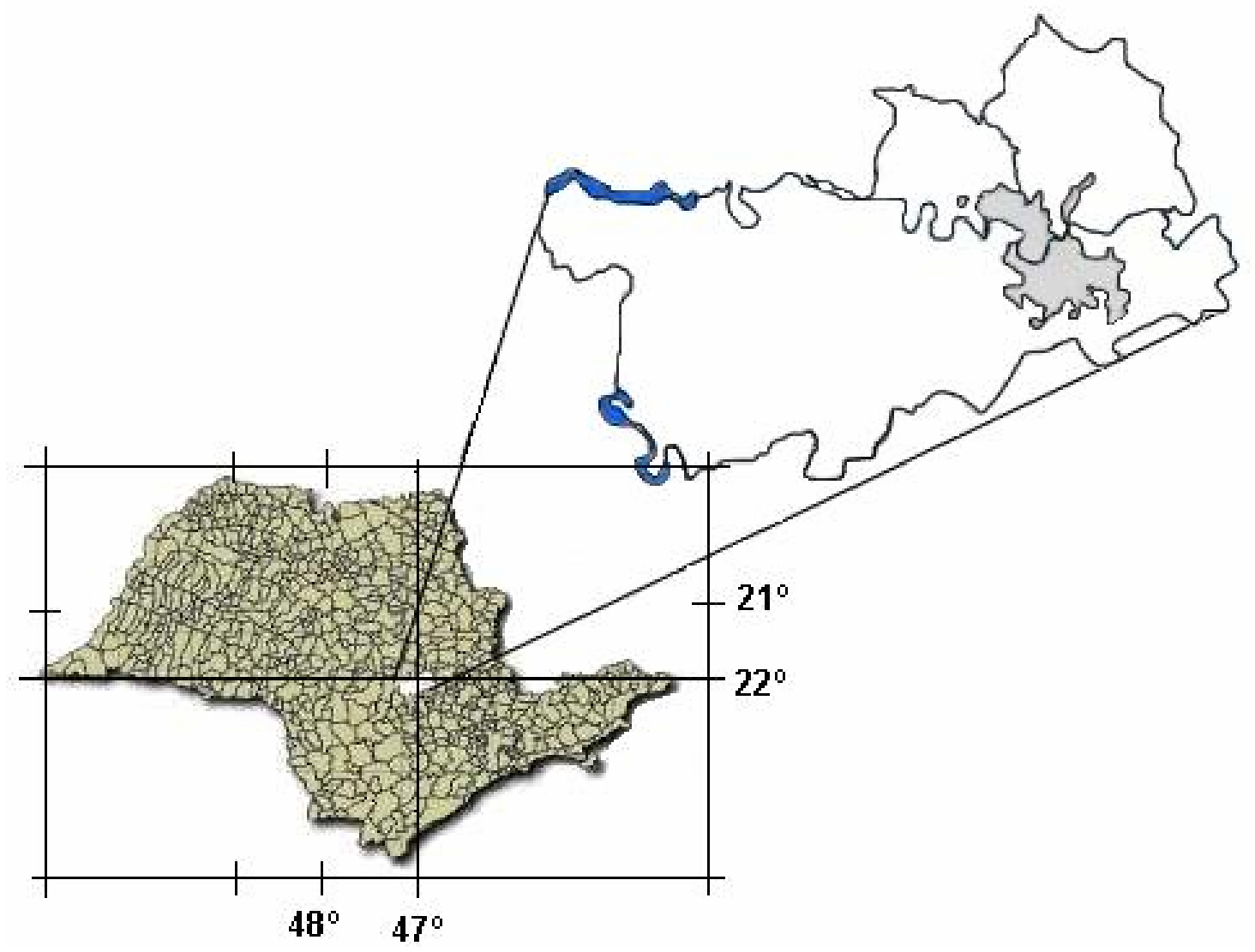

Figura 1- Localização de Piracicaba no Estado de São Paulo

\subsubsection{Aspectos da geografia física do município}

\subsubsection{Clima}

A área de Piracicaba situada em ponto crítico de transição das correntes da circulação geral, apresenta características climáticas variadas. Essa variabilidade ocasiona dois períodos distintos: um mais quente e chuvoso e outro menos quente e mais seco. 
Essa variabilidade, própria das regiões de transição torna difícil enquadrar a área de Piracicaba numa classificação climática. Há para essa região uma tendência para a tropicalidade: temperaturas médias anuais em torno de $20^{\circ} \mathrm{C}$; a média dos meses mais quentes (Novembro/ Março) atinge $23^{\circ} \mathrm{C}$ e dos meses mais frios (Maio/ Agosto) cerca de $17^{\circ} \mathrm{C}$ (RANZANI, 1996).

\subsubsection{Geomorfologia e Solos}

O município de Piracicaba pode ser considerado privilegiado em relação aos seus tipos de solos. Eles são diversificados e juntamente com as formas do relevo faz com que ocorram solos distintos.

De uma maneira simplificada, na porção nordeste do município predominam solos que apresentam textura média à argilosa.. São profundos e apresentam elevada capacidade de retenção de água. Sua fertilidade é variável, predominando as classes de baixa fertilidade que necessitam de correção e adubação para atingir elevada produtividade. Nessa porção o relevo é predominantemente plano ou suave ondulado, ocasionando o intenso cultivo da cana-de-açúcar.

A porção norte do município que drena para o Rio Corumbataí e a maior parte de sua porção central e sul são ocupadas por associações de Podzólicos preenchidas com manchas menores de uma grande diversidade de solo (Brunizens, Litólicos, Pozol, Cambissolos).

Na região oeste do município o relevo é mais suave, devido ao substrato rochoso. Os solos são arenosos. As areias Quartzosas e os Podzólicos e Litólicos arenosos predominam.

O município de Piracicaba apresenta uma depressão maior na parte central de seu território. Esta depressão segue o sentido Leste - Oeste do curso do rio Piracicaba, ficando mais acentuada dentro dos limites da área urbana a partir do salto do Rio Piracicaba. Os vales que convergem para o Rio Tietê na região Sudoeste e para o Rio Piracicaba na região central indo para o Norte - Noroeste provocam depressões 
relativamente acentuadas ou regiões de encaixe maior da rede de drenagem dependendo das características do material geológico. A amplitude da altitude é de 360m com as regiões mais baixas com cerca de $420 \mathrm{~m}$ e as mais elevadas com $780 \mathrm{~m}$. A altitude média é de $528 m$.

\subsubsection{Hidrografia}

A rede hidrográfica de Piracicaba se estende por $2.139 \mathrm{~km}$. A densidade da rede de drenagem acompanha o relevo, sendo mais ramificada nas terras mais movimentadas da porção central e norte do município. Nas bacias de $3^{\mathrm{a}}$ e $4^{\mathrm{a}}$ ordem e em muitos outros casos, é nitidamente controlada pelas estruturas geológicas, reveladas por segmentos retilíneos nos rios principais. Os rios maiores (Piracicaba e Tietê) se encontram parcialmente represados na região oeste.

O rio Piracicaba é o grande destaque e corta quase ao meio o município. Sua origem encontra no Planalto Atlântico, vertente ocidental da Serra Geral. O encontro dos rios Atibaia e Jaguari na região de Americana forma o início do rio Piracicaba que percorre todo o município de Piracicaba e deságua no rio Tiête.

A figura 2 mostra as 37 bacias hidrográficas, que compõem a rede de drenagem do município de Piracicaba. 


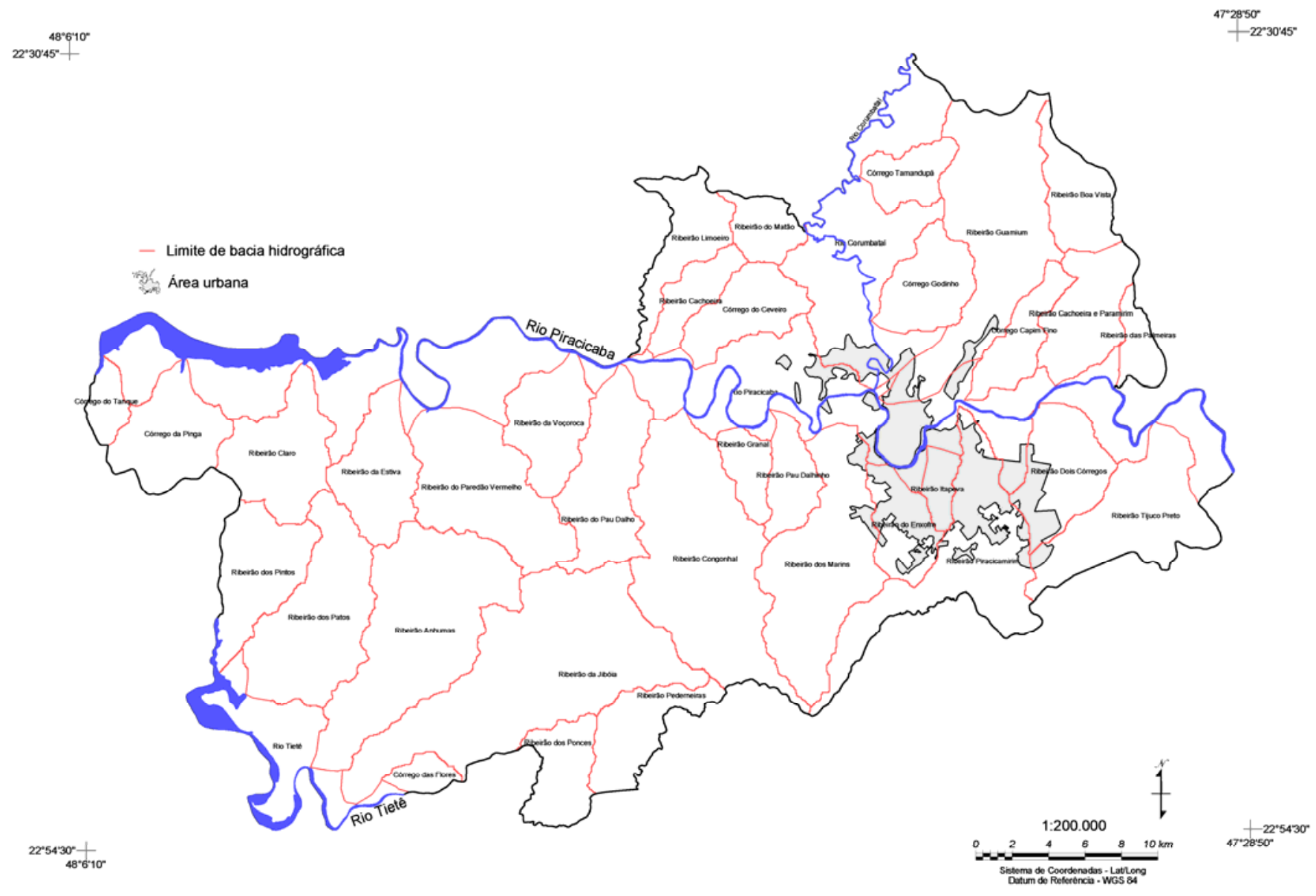

Figura 2- Mapa da hidrografia do Município de Piracicaba

Fonte: PDRP, 2004 


\subsubsection{Vegetação}

A área com cobertura florestal no município soma aproximadamente 27.600ha. Destes, 22.100ha estão localizados fora de áreas de proteção permanentes (APPs) e 5.500ha dentro. A maior parte das reservas florestais do município se localiza na região oeste, onde predominam fragmentos maiores e mais contínuos. Na região próxima ao perímetro urbano e nas áreas de cultivo mais intensivo e antigo de cana-deaçúcar as florestas aparecem em menor quantidade e mais isoladas.

\subsubsection{5 Área urbana de Piracicaba}

A área urbana de Piracicaba esta dividida em cinco zonas principais: Zona Central, Zona Norte, Zona Sul, Zona Leste e Zona Oeste. A figura 3 contém o atual zoneamento urbano da cidade de Piracicaba. 


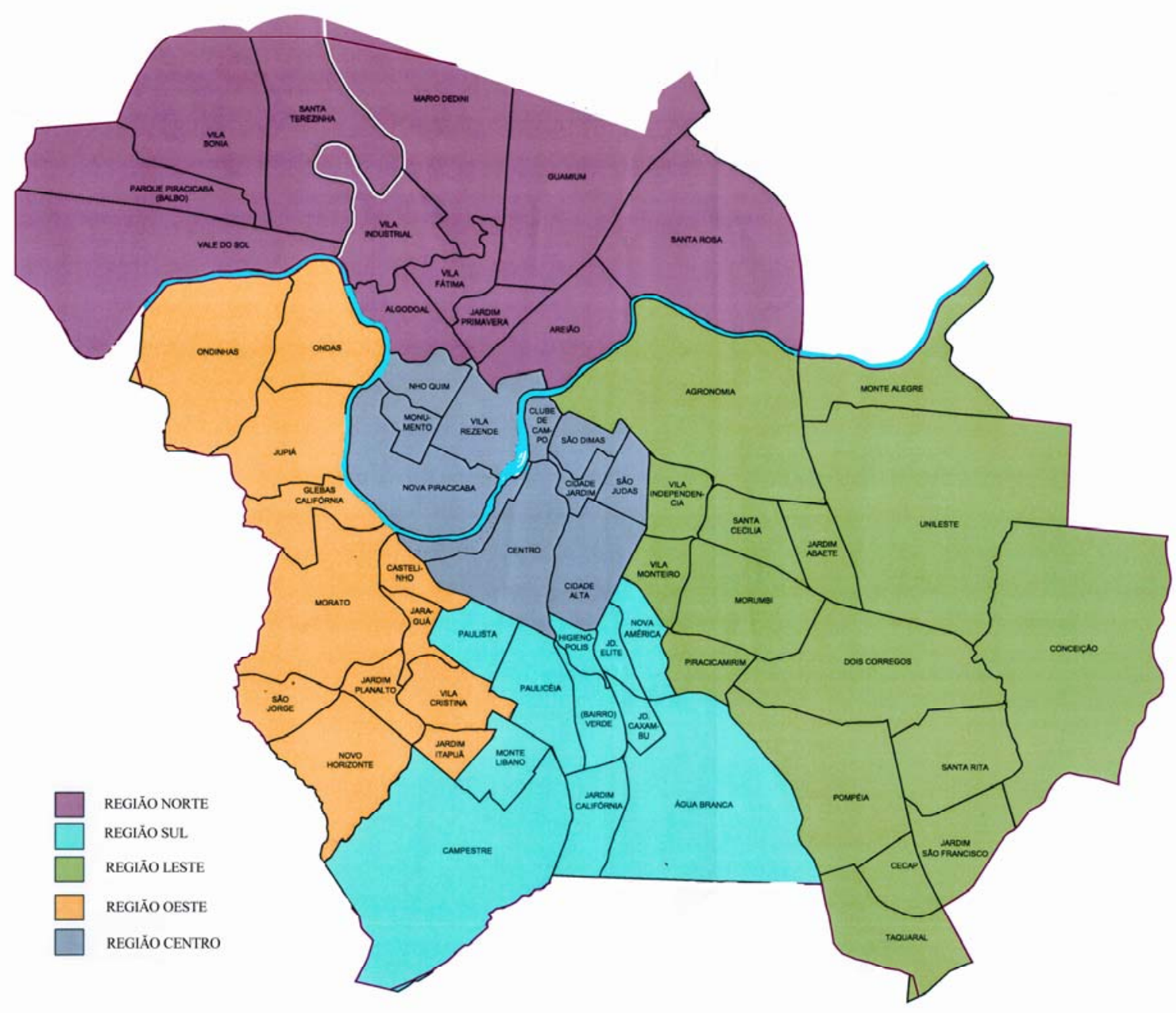

Figura 3- Mapa do Zoneamento Urbano de Piracicaba

Fonte: Prefeitura Municipal de Piracicaba - 2000

\subsection{Síntese da caracterização da área em estudo}

A cidade de Piracicaba é um espaço urbano de extrema importância no território paulista e brasileiro, pois se mostra um pólo agroindustrial de grande destaque. A cultura e história que permeia a cidade revelam a existência de um dos recursos 
naturais mais importantes para o homem, a água. O rio Piracicaba acaba atraindo olhares para o espaço urbano de forma a evidenciar o aspecto ambiental.

\subsection{Procedimento da pesquisa}

O trabalho foi dividido em quatro etapas principais:

A primeira constou do levantamento das fotografias áreas em cinco momentos distintos entre 1940 e 2000, que resultou nos anos de 1940, 1962, 1978, 1995 e 2000 .

A segunda fase foi a realização do georreferenciamento das fotografias áreas e a fotointerpretação dos mosaicos gerados.

A terceira fase foi direcionada ao levantamento bibliográfico.

A quarta fase foi à discussão dos resultados e a elaboração da conclusão final.

\subsubsection{Levantamento das fotografias aéreas}

O projeto teve como primeira etapa reconstruir a expansão urbana da cidade de Piracicaba. Para isso, foram utilizadas fotografias aéreas dos anos de 1940, 1962, 1978, 1995 e 2000 (Tabela 1).

O primeiro período corresponde à mancha urbana de 1940, quando foi registrado o primeiro vôo aéreo com a finalidade de fotografar a cidade. O segundo período mostra a malha urbana em 1962. O terceiro período corresponde ao limite urbano de 1978. O quarto período mostra o limite urbano em 1995. O quinto período é o limite atual da cidade, registrado em 2000. O critério usado para delimitar os perímetros urbanos em cada mosaico foi o sistema viário e aonde se visualizava o arruamento com a presença de construção urbana.Veja a tabela 3, onde os períodos, escalas, empresa executora e locais cedentes das fotografias áreas usadas nesta pesquisa foram organizados. 
Tabela 3. Materiais utilizados para a definição do perímetro urbanizado de Piracicaba (SP) entre 1940 a 2000 , escala, empresa executora e cedente

\begin{tabular}{|c|c|c|c|c|}
\hline $\mathrm{ANO}$ & FOTOS & ESCALA & EMPRESA EXECUTORA & CEDENTE \\
\hline \multirow[t]{3}{*}{1940} & 11 Fotos Aéreas & 1: 20.000 & Cruzeiro do Sul & Departamento de Engenharia Rural - Setor de \\
\hline & & & $\mathrm{S} / \mathrm{A}$ & Topografia \\
\hline & & & & ESALQ/USP \\
\hline \multirow[t]{3}{*}{1962} & 07 Fotos Aéreas & 1: 25.000 & Terrafoto Atividades de & Centro de Energia Nuclear na Agricultura \\
\hline & & & Aerolevantamento & CENA/USP \\
\hline & & & S/A & \\
\hline \multirow[t]{3}{*}{1978} & 13 Fotos Aéreas & $1: 35.000$ & Terrafoto Atividades de & Departamento de Engenharia Rural - Setor de \\
\hline & & & Aerolevantamento & Topografia \\
\hline & & & $\mathrm{S} / \mathrm{A}$ & ESALQ/USP \\
\hline \multirow[t]{2}{*}{1995} & 14 Fotos Aéreas & 1: 25.000 & Base Aerofotogrametria & Prefeitura do Campus “Luiz de Queiroz” \\
\hline & & & S/A & PCLQ/USP \\
\hline \multirow[t]{2}{*}{2000} & 16 Fotos Aéreas & $1: 30.000$ & Base Aerofotogrametria & Prefeitura Municipal de Piracicaba \\
\hline & & & S/A & \\
\hline
\end{tabular}




\subsubsection{Georreferenciamento e fotointerpretação}

Organizadas as fotografias áreas, como primeiro passo foi realizado uma fotointerpretação com auxílio de estereoscópio, possibilitando a classificação do uso, especialmente em relação à cobertura vegetal mais próxima ao perímetro urbano de cada período selecionado. Depois as fotografias foram convertidas para o formato digital matricial (tif). Em todas as fotografias foram utilizados "scanners" e padronizou-se em 300 dpi a resolução para as imagens de trabalho e posteriormente foram georreferenciadas. O georreferenciamento das imagens foi realizado através de um receptor GPS diferencial (GeoExplorer II) e foram determinados 137 pontos referenciais (verdade terrestre). As fotografias foram transferidas para o Sistema de Informações Geográficas TNT Mips 6.0, onde foi feito o georreferenciamento das imagens tomando, no mínimo, 4 pontos de controle para cada uma. O erro médio de georreferenciamento obtido foi de 1,5 pixels, o que, considerando-se as distorções inerentes aos materiais originais antigos, pode ser considerado bastante satisfatório, porém não foi feita correção ortogonal e possíveis erros de georreferência pelo uso de mosaicos de fotos antigas aconteceram em pequenos locais. Foram utilizados o sistema de coordenadas geográficas (LAT/LONG) e o Datum WGS 1984.

Foram criados os mosaicos digitais que serviram de base para a digitalização dos polígonos. O critério utilizado para consideração de área urbanizada foi o reticulado característico de quarteirões associado a edificações. Dessa forma, procurou-se criar condições para uma subseqüente análise comparativa dos dados, entretanto, em função de se estar trabalhando com diferentes fontes de imagens em distintas escalas, é possível que a subjetividade seja perceptível em níveis de maior acuidade.

A área do periurbano foi visualizada em relação ao perímetro urbano de cada período num correspondente a escala de cada mosaico, sempre procurando ressaltar as áreas aonde a ligação viária era mais intensa entre o urbano e o rural. 
Uma distância um pouco maior do que o perímetro urbano de 2000 foi usado como modelo para delimitar as análises dentro dos mosaicos de 1940, 1962, 1978, 1995 e 2000, localizando as áreas de cobertura vegetal que mais se tornaram evidentes em cada período.

A figura 4 é um exemplo de mosaico. Este exemplo é o mosaico de 1940. Semelhantes a este foram originados os mosaicos de 1962, 1978, 1995 e 2000.

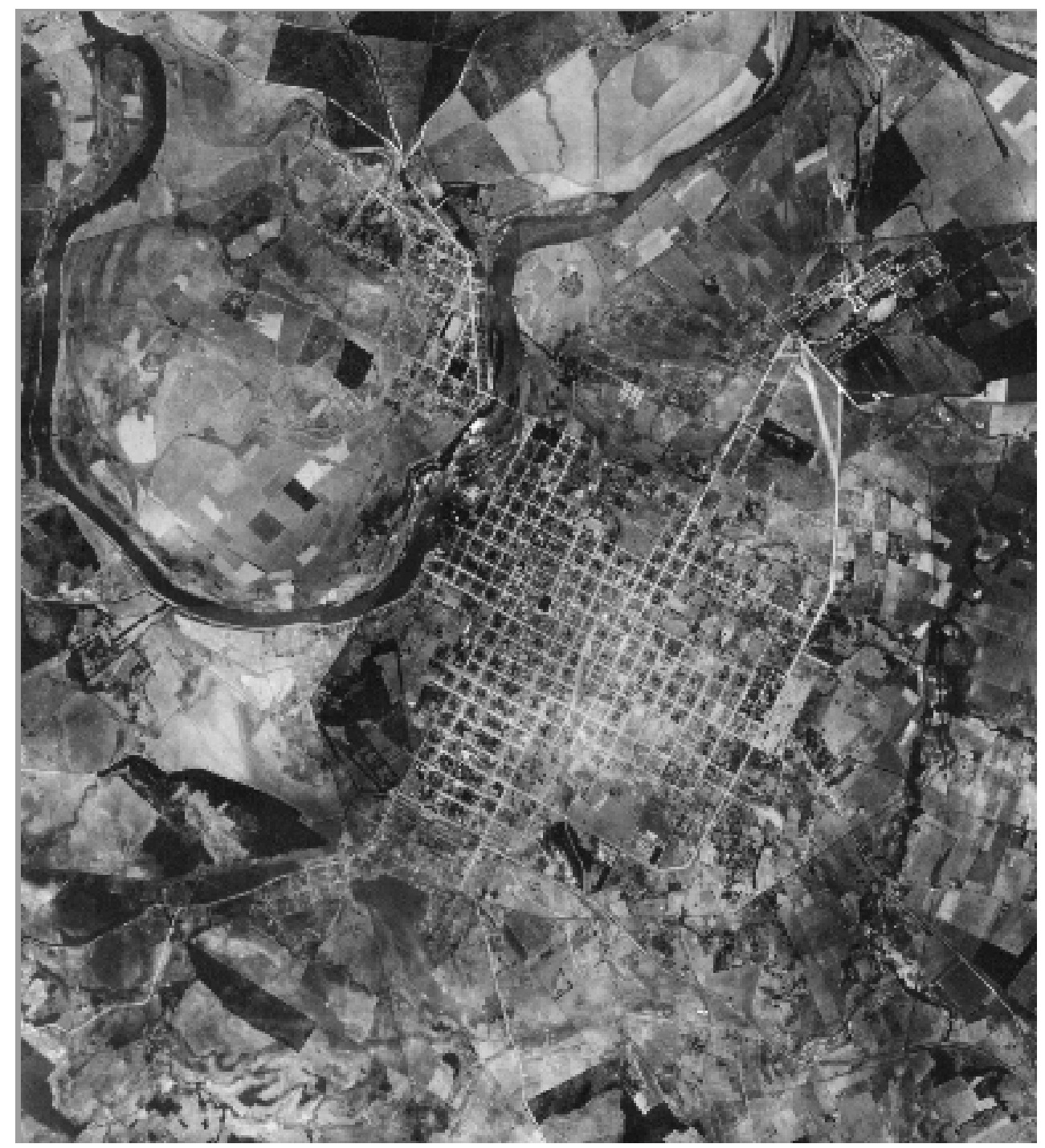

Figura 4- Mosaico de 1940 


\subsubsection{Critérios utilizados na área de estudo}

O limite dos perímetros urbanos em cada período foi definido tomando como referencial o sistema viário das bordas da estrutura urbana. A presença de arruamento com característica de quarteirões associada a edificações, foi usado para que o limite territorial entre o urbano e o periurbano fosse estabelecido.

Foi delimitado um perímetro um pouco maior do que a área urbana consolidada do ano 2000, para que a delimitação da cobertura vegetal fosse registrada. A partir desse limite foi processada a observação.

Foi considerada parte da cobertura vegetal delimitada, diferentes tipos de áreas, entre elas estavam, áreas de mata, reflorestamento, pasto, agricultura diversas e áreas de proteções permanentes (APPs). O critério principal para evidenciar uma área como integrante do que seria cobertura vegetal foi à presença de árvores no local.

\subsubsection{Levantamento bibliográfico}

O levantamento bibliográfico reuniu temas relativos aos problemas ambientais urbanos, ressaltando a questão sobre a importância de se ter áreas com cobertura vegetal natural para que estas possam atuar como áreas verdes, espaços públicos, praças, jardins, etc, dentro da área urbana. Outro enfoque da revisão bibliográfica foi sobre temas que mostraram a importância de se estudar as áreas periurbanas para auxiliar planejamentos urbanos.

\subsubsection{Discussão e conclusão}

Esta etapa constou de mapas, tabelas, análises e sugestões quanto aos vetores de crescimento urbano e quanto aos locais de frações de cobertura vegetal nos períodos de 1940, 1962, 1978, 1995 e 2000, bem como a elaboração da conclusão final do trabalho. 


\subsection{Síntese do material e método}

A pesquisa que embasou este trabalho foi desenvolvida através dos seguintes procedimentos: inicialmente foram organizadas fotografias aéreas dos anos de 1940, 1962, 1978, 1995 e 2000. Estas foram georreferenciadas e fotointerpretadas. Foram lidos textos ligados ao tema proposto e organizada uma bibliografia correspondente. Os resultados foram discutidos e ocasionaram a conclusão do trabalho. 


\section{RESULTADOS E DISCUSSÃO}

\subsection{Período de 1940}

A cidade de Piracicaba começou a se organizar em meados do século XVIII, mais precisamente em $1^{\circ}$ de Agosto de 1767, sob a direção de Antônio Corrêa Barbosa, que viu nas terras férteis um vasto caminho para agricultura e também se orientou para as reservas de madeira, a fim de fornecer matéria-prima para a fabricação de canoas, responsáveis pelo abastecimento da região de Cuiabá e de Iguatemi. A produção organizava-se numa forma mista de economia extrativa e manufatureira (POMPERMAYER, 1998). A terra fértil proporcionou o cultivo agrícola e acabou condicionando a imigração para a região. “A área de Piracicaba, deve seu povoamento em maior escala em função ao cultivo da cana-de-açúcar” (PETRONE, 1968).

A partir da década de 1940, a exemplo de todo o Sudeste brasileiro, Piracicaba experimentou uma diversificação da estrutura industrial com um nítido crescimento no ritmo de implantação fabril. Piracicaba refletiu em parte o dinamismo manufatureiro que, impulsionado inicialmente pela II Guerra Mundial, se propagou e intensificou nas décadas de 1950 e 1960 no Brasil, principalmente na atual região Sudeste e, dentro dela, especificamente no Estado de São Paulo (SAMPAIO, 1976).

Esse fenômeno confere à cidade a função de centro de produção econômica e a diversificação de atividades gera uma elevação na complexidade da estrutura social que se reflete quantitativamente no aumento populacional e no crescimento físico da mancha urbana. 
A figura 5 mostra o limite urbano de 1940 e os polígonos das frações da cobertura vegetal desde período, evidenciando a forma urbana acanhada e ainda de aspecto colonial, mas que a partir de então começa a mudar a sua fisionomia.

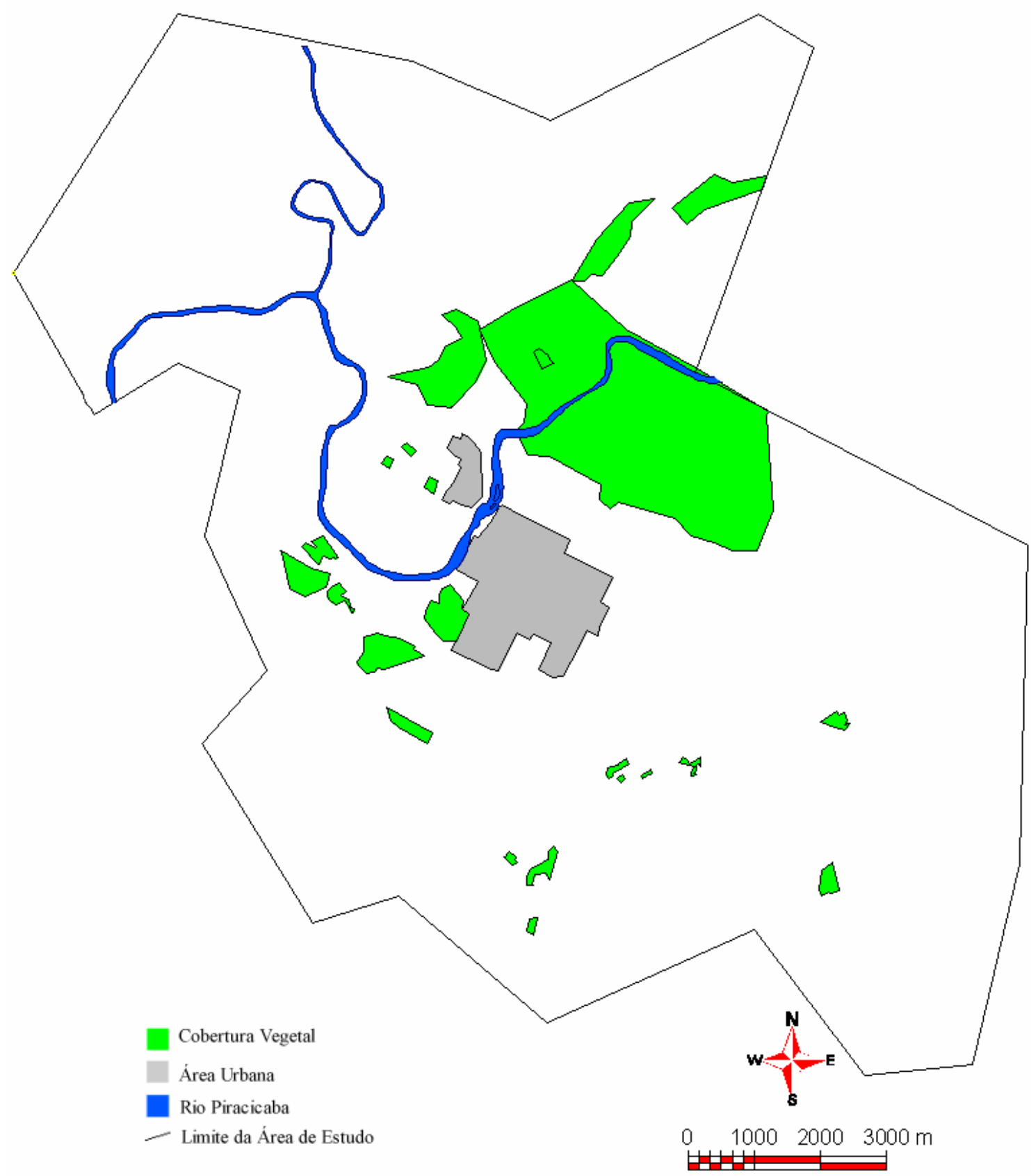

Figura 5- Perímetro Urbano e Áreas de Cobertura Vegetal de 1940 
O perímetro urbano de 1940 foi oficializado em 1939 pela Ata da Câmara Municipal de Piracicaba. No dia 23 de Novembro criava-se o $10^{\circ}$ Perímetro Urbano da cidade (Tabela 6) e ele correspondia à seguinte descrição: "começando no cruzamento da rua José Ferraz de Camargo com a Avenida Independência, segue pelo eixo desta avenida até o ponto em que ela é cortada pela rua Silva Jardim, continua deste ponto, em reta, até o cruzamento da rua Benjamin Constant com a Avenida D.Jane, segue pelo eixo desta até o seu cruzamento com a rua Tiradentes, continua pelo eixo desta rua até o seu cruzamento com a rua Riachuelo, segue pelo eixo do prolongamento desta até encontrar a margem esquerda do rio Piracicaba, sobe por esta margem até encontrar a rua Rangel Pestana, vai daí, por uma reta, até o cruzamento da avenida Dr.Américo Brasiliense com a rua Estevão, segue pelo eixo desta até o cruzamento com a rua Dr.Eulálio, continua até o ponto situado a $500 \mathrm{~m}$ desse cruzamento, pelo eixo do prolongamento da rua Dr.Eulálio, deflete, nesse ponto à direita, em ângulo reto, até encontrar o prolongamento da avenida Conceição, desse cruzamento, numa reta, o cruzamento da avenida Independência com a rua José Ferraz de Camargo, ponto inicial desta divisa” (POMPERMAYER,1998). As delimitações dos perímetros urbanos deste trabalho foram originadas a partir das interpretações dos mosaicos, tomando como referencial o sistema viário. A descrição correspondente ao perímetro urbano de 1939 confirmou o traçado elaborado neste trabalho para o perímetro urbano de 1940.

Na década de 1940 a cidade de Piracicaba possuía 76.416 habitantes e concentrava-se na área central e na Vila Rezende. A população rural era maior do que a população urbana na seguinte proporção: 33.771 hab/urbano e 42.645 hab/rural.

"A malha urbana cresce, e a cidade passa a adotar-se de vários equipamentos urbanos. Seus habitantes avolumam-se, com a vinda de trabalhadores imigrantes. Sua principal riqueza econômica vai estar na produção da cana-de-açúcar. Ela vai ser o seu principal indutor de desenvolvimento" (POMPERMAYER,1998). Assim, o núcleo urbano passa a ser um espaço contraditório da produtividade e da 
racionalidade capitalista (LOJKINE, 1981). A cidade cresceu e desenvolveu-se apropriando de diversos espaços.

A área central era formada pelos seguintes bairros: São Dimas, São Judas, Cidade Jardim, Clube de Campo, Cidade Alta, Centro, Vila Rezende e parte pequena ao nordeste da Nova Piracicaba.

As áreas de cobertura vegetal de maiores destaques se localizavam na porção oeste e norte, sendo que a predominância já era o plantio da cana-de-açúcar, com pequenas manchas de pastos e florestas até mesmo entre as construções urbanas.

O Parque do Mirante e Engenho Central apresentavam uma tímida mata ciliar, mesmo assim eram as áreas mais evidentes de mata às margens do rio Piracicaba. A chácara Nazareth (W) e o parque da Esalq (NE) eram as frações de verdes de maiores tamanhos próximas à área urbana, sendo que respectivamente mediam $357 \mathrm{mil} \mathrm{m}^{2}$ e $984 \mathrm{mil} \mathrm{m}^{2}$.

A cobertura vegetal localizada à oeste eram frações maiores com áreas entre $372 \mathrm{mil} \mathrm{m}^{2}$ e $70 \mathrm{mil} \mathrm{m}^{2}$. Ao sul e leste os fragmentos eram menores e com grande distanciamento entre um fragmento e outro. Neste período as somas totais das áreas de cobertura vegetal somaram $13.439 \mathrm{mil} \mathrm{m}^{2}$.

No lado leste existia uma mata de eucalipto e uma área pobre em espécies arbóreas. Em todas as direções se evidenciava um periurbano de cultivo da cana e em alguns pontos a leste o cultivo do café e da laranja.

A Figura 6 mostra as áreas de cobertura vegetal no período de 1940 integrando estas áreas com os limites urbanos de cada período, evidenciando o sentido de crescimento da cidade. 


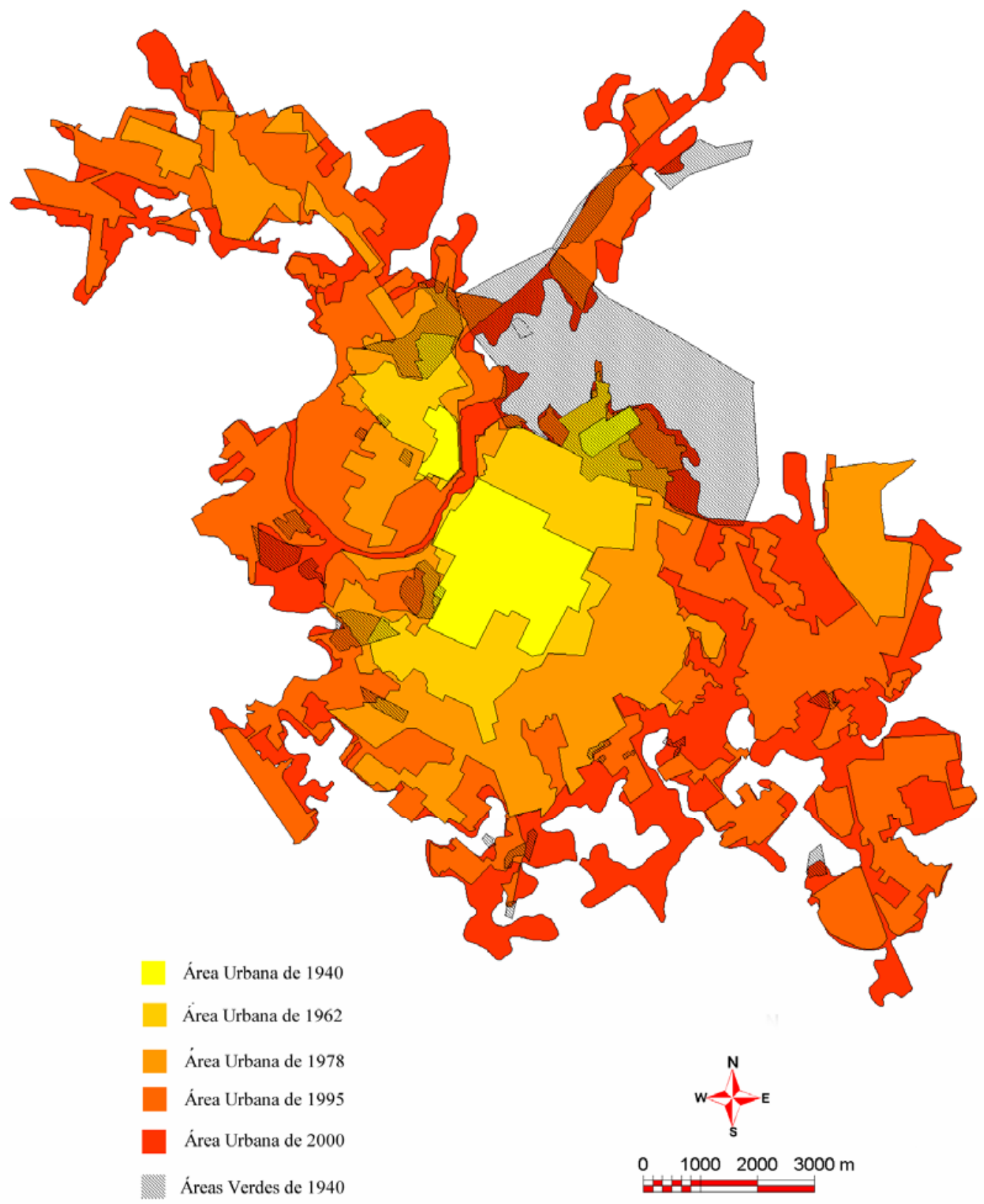

Figura 6- Perímetros Urbanos de 1940 a 2000 e Áreas de Cobertura Vegetal de 1940 


\subsection{Período de 1962}

Entre os anos 1960 e 1978, o Brasil vivencia uma vertiginosa industrialização com um crescimento médio da economia de 10,9\% ao ano em função da entrada de capital e de tecnologia provenientes das grandes empresas multinacionais (SCARLATO, 1996). Nessa época o capitalismo paulista comandou a transferência da indústria pesada da metrópole para o interior e Piracicaba foi uma das cidades de destino dessa indústria. "Os imigrantes chegam atraídos pela oportunidade de emprego nas inúmeras indústrias multinacionais que se instalam no distrito industrial do Município de Piracicaba” (POMPERMAYER,1998).

No final da década de 60, inicia-se a expansão acentuada de toda a periferia da cidade, ultrapassando a leste o ribeirão Piracicamirim, a noroeste Santa Terezinha e ao sul o bairro da Paulicéia.“Os loteamentos cresceram por todos os lados, ao sabor dos interesses da iniciativa privada, trazendo consigo as marcas negativas do mau uso do solo, com evidentes prejuízos sobre a qualidade de vida urbana” (LEÃO,1988).

Em 1960 a população de Piracicaba era de 115.403 habitantes. A inversão campo/urbano aconteceu entre o período anterior e este, sendo que na área urbana houve uma contagem de 82.303 habitantes e na área rural de 33.887 habitantes.

Neste período a cobertura vegetal, dentro e fora do limite urbano apresenta um aumento em áreas e em número de fragmentos. A figura 7 mostra o limite urbano de 1962 e os polígonos da cobertura vegetal desse perímetro. Ficou evidente o quanto de cobertura vegetal surgiu entre 1940 e 1962. 


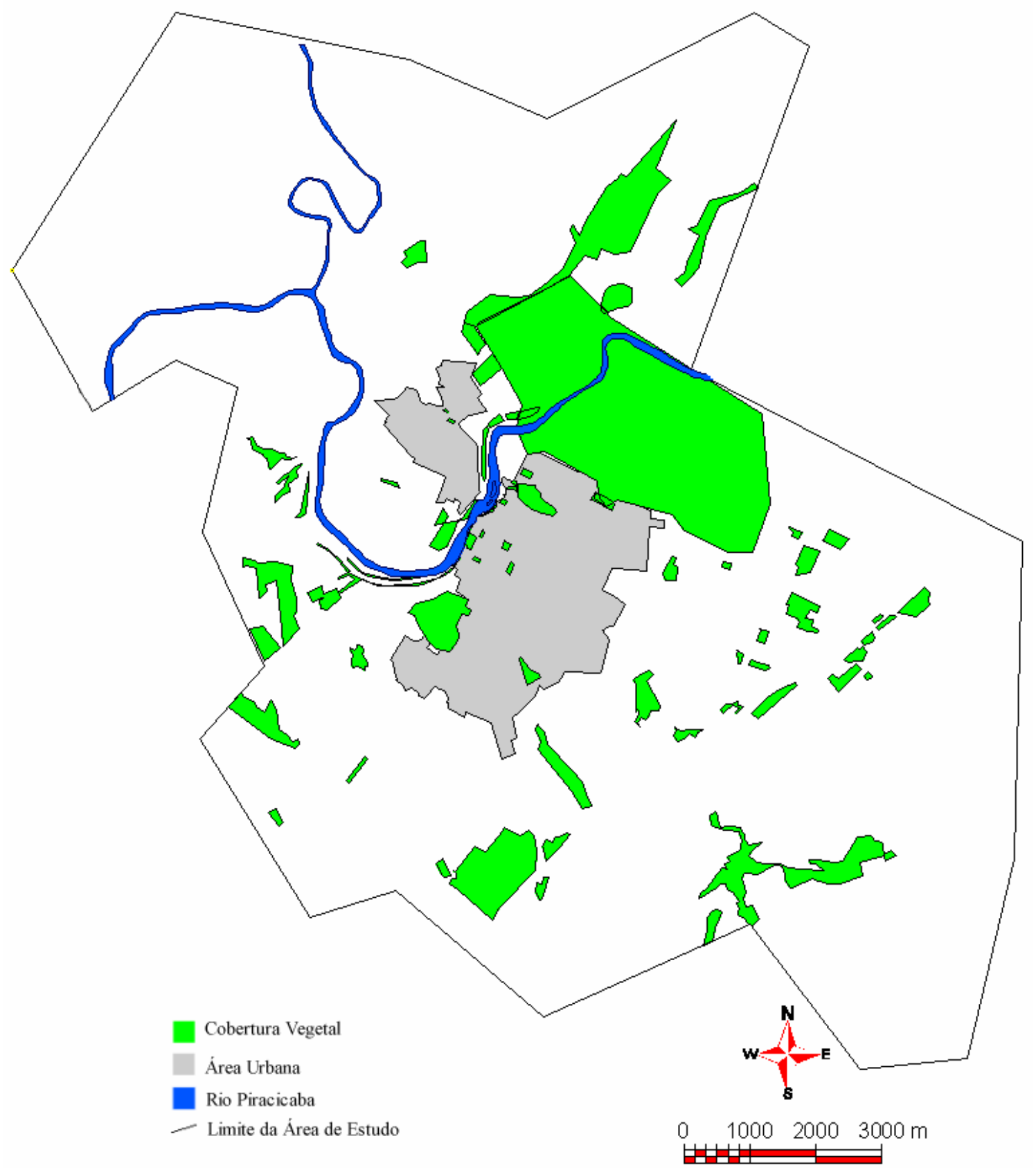

Figura 7- Perímetro Urbano e Áreas de Cobertura Vegetal de 1962 
Em se tratando da cobertura vegetal dentro da área urbana, a Chácara Nazareth mostrou um aumento em sua cobertura verde, pois foi possível visualizar aumento nas copas arbóreas, porém o Engenho Central apresentou uma diminuição na fração de sua cobertura vegetal, revelando a chegada urbana em seu entorno. A chácara Nazareth e o parque da Esalq, apresentaram as respectivas somas em sua cobertura vegetal, 496mil m² e 9.771 mil m². A chácara Nazareth (W) e o parque da Esalq (NE) continuaram sendo a expressão mais abundante da cobertura vegetal nas proximidades da área urbana, sendo que ao norte da Esalq apareceu um núcleo de mata ao longo da rodovia SP 147, Piracicaba-Limeira. O sul, sudeste, leste e nordeste evidenciam o surgimento de pequenas manchas de floresta onde antes era pasto e cana.

A cidade cresceu em direção a Esalq e acabou invadindo parte da área da cobertura vegetal próxima ao limite da Escola. Outro vetor de crescimento urbano se deu na direção noroeste, mas não houve o encontro com nenhuma área natural de verde neste setor. A mata ciliar do rio Piracicaba ficou mais evidente do que no período de 1940 e frações verdes apareceram ao lado das margens do rio entre a estrutura urbana e o rio em ambas as direções.

A região oeste apresentou um aumento no tamanho dos polígonos e na quantidade de frações da cobertura vegetal. Ao sul frações menores das que apareceram à oeste, foram identificadas e muitas delas formando um aglomerado de verde com presença de muitas árvores. A região sudeste foi caracterizada neste período, com número relativamente alto de frações verdes, formando núcleos e pontos de uma importante cobertura vegetal. A expansão da cidade, diagnosticada no próximo período, se processou em direção sudeste e se as áreas de cobertura vegetal identificadas em 1962, tivessem sido preservadas, poderiam ter exercido grande diferencial no ambiente urbano desta região, o que não ocorreu. Na região leste surgiram fragmentos novos na cobertura vegetal e eles não foram visualizados no período de 1940, confirmando o relativo aumento entre 1940 e 1962 . Neste período as somas totais das áreas de cobertura vegetal somaram de $18.069 \mathrm{mil} \mathrm{m}^{2}$. Das épocas analisadas este foi o segundo melhor 
período de presença e preservação da cobertura vegetal dentro e fora do perímetro urbano de Piracicaba.

Além dos bairros já existentes, a cidade foi acrescida por novos bairros. Surgiram na parte central, o bairro Nho Quim, Monumento e parte leste e sul da Nova Piracicaba; na região leste: Vila Independência, Vila Monteiro, Santa Cecília, Morumbi, Piracicamirim e houve um adensamento de construções urbanas nas proximidades da agronomia (Esalq). Na região sul surgiu o bairro da Nova América, Jardim Elite, Higienópolis, Paulista e parte da Paulicéia. Na região oeste: Castelinho e Jaraguá. Na região norte: Parte do Areião e Jardim primavera.

No final da década de 60, o êxodo rural, eleva o número dos habitantes das cidades. Em todo o país, as cidades começam a ter dificuldades para abrigar todos os seus novos habitantes, surgindo como conseqüências as primeiras favelas (POMPERMAYER, 1998). Essa realidade também foi constatada em Piracicaba com o surgimento de bairros pobres na direção noroeste (Santa Terezinha) e sul (Paulicéia).

A figura 8 mostra os perímetros urbanos em 1940 e 1962, juntamente com a cobertura vegetal de 1962. Nela se registrou o quanto da cobertura verde poderia ter se tornado em áreas ambientais para a cidade, fornecendo ao ambiente condições de reoxigenação, retenção de pó, minimização de ruídos, dentre outros benefícios. 


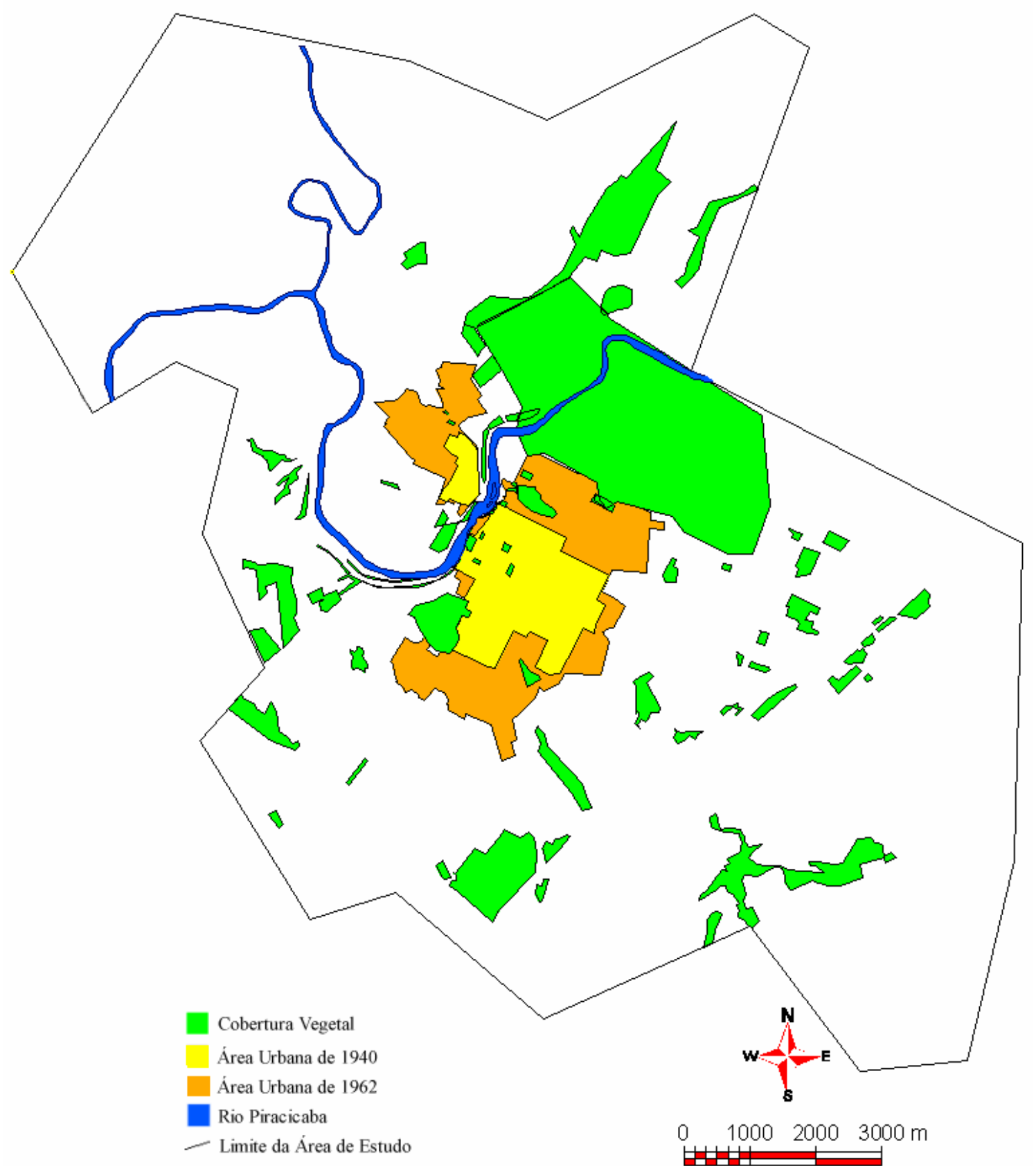

Figura 8- Perímetros Urbanos de 1940 e 1962 e Áreas de Cobertura Vegetal de 1962 


\subsection{Período de 1978}

Os anos 80 significaram para o Brasil um acentuado processo de desaceleração da sua economia. Entretanto, cidades médias como Piracicaba passaram a ter taxas de crescimento econômico superiores às da capital. $\mathrm{O}$ resultado foi o aumento da participação das cidades do interior no produto industrial do Estado, e conseqüente manutenção do ritmo de crescimento físico e populacional (GROSTEIN, 2001).

Na década de 70 a cidade ultrapassou os limites tradicionais, atingindo o Ribeirão Piracicamirim a leste, o Ribeirão do Enxofre ao sul , e expandindo na direção noroeste, com o crescimento considerável do distrito de Santa Terezinha. Surgiram muitos loteamentos distantes da malha urbana, bem como alguns núcleos habitacionais. A conjuntura econômica da época, aliada à vinda de grandes indústrias e a implantação do Distrito Industrial (Unileste), contribuíram para a ocorrência de um aumento imobiliário na cidade (PDDP,1991).

Novas vias foram abertas e as principais vias foram reformuladas interligando a cidade de norte-sul e leste-oeste. "Com a finalidade de diminuir o transito de veículos da área central e encurtar o tempo de percurso entre as cidades vizinhas, foi construindo em 1987, o anel viário, que acabou se tornando um atraente de moradias populacionais” (POMPERMAYER, 1998). A partir de 1980 intensificou o crescimento vertical da cidade.

Em 1978 não houve censo em Piracicaba, porém os dados do censo de 1980, registraram um total de 214.295 habitantes no município, sendo que 197.904 hab/urbano e 16.391 hab/rural, evidenciando o processo de êxodo rural e o crescimento populacional da área urbana neste período.

A figura 9 mostra o limite urbano de 1978 e a cobertura vegetal que existia neste período, evidenciando o desaparecimento de frações verdes que tinham sido registradas em 1962. A expansão urbana que se processou durante 1962 e 1978 resultou na diminuição da cobertura vegetal dentro e no entorno urbano de Piracicaba. 


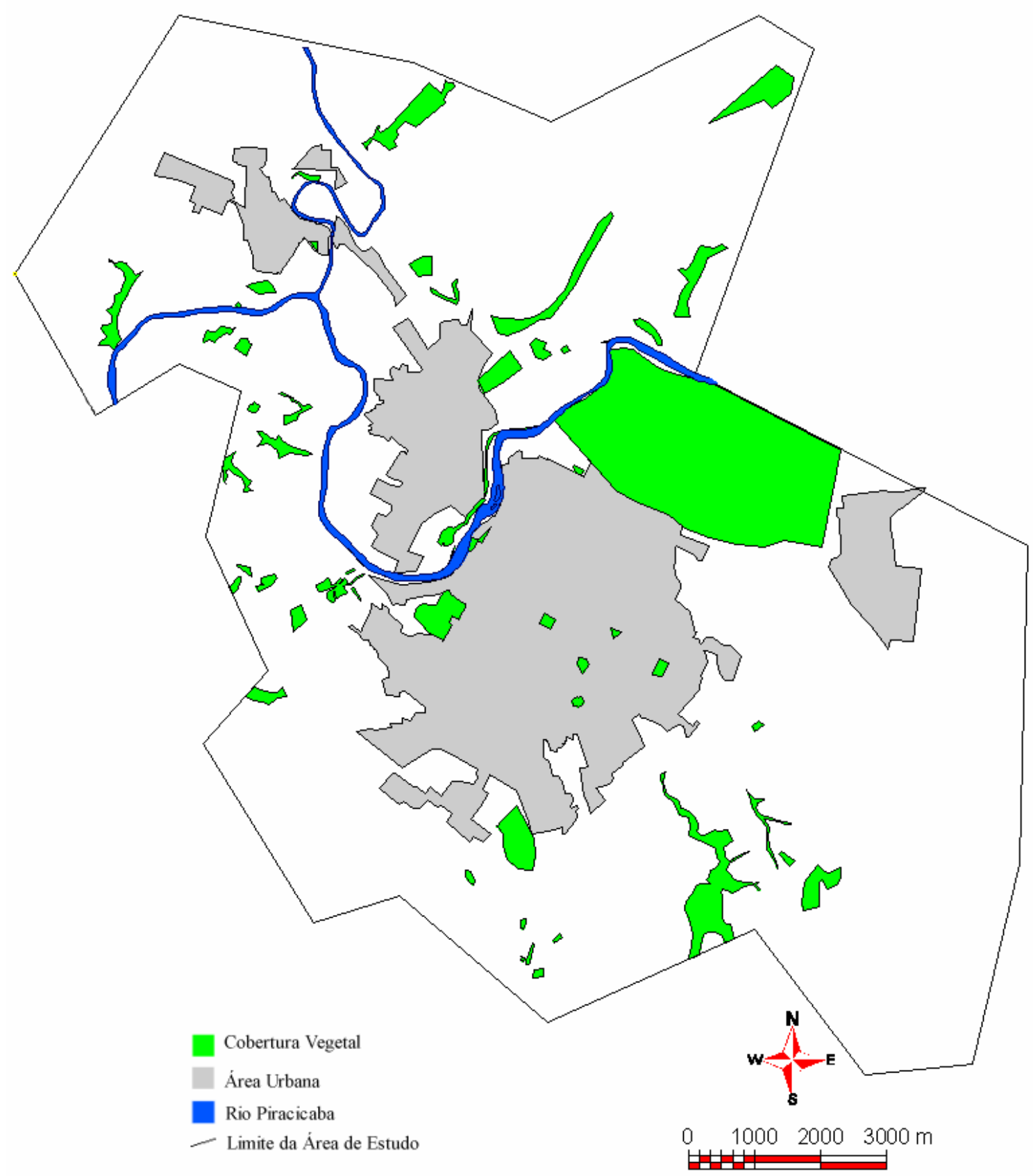

Figura 9- Perímetro Urbano e Áreas de Cobertura Vegetal de 1978

A chácara Nazareth e o parque da Esalq sofreram uma redução no tamanho da sua cobertura vegetal, apresentando suas áreas em $306 \mathrm{mil} \mathrm{m}^{2}$ e $7.626 \mathrm{mil} \mathrm{m} \mathrm{m}^{2}$ respectivamente. Houve uma separação nos núcleos da cobertura vegetal ao norte da Esalq. Ficou visível o fim das áreas de cobertura vegetal que existiam ao leste e ao sul 
da cidade, sendo este os dois principais vetores de crescimento urbano em 1978. Na região oeste ocorreu perda e separação de frações verdes que foram registradas no período de 1962.

A cobertura vegetal das regiões norte e oeste foram trocados pela construção e equipamentos urbanos e a cidade se direcionou para o vetor noroeste, desaparecendo nesta direção a cobertura vegetal, inclusive plantios de cana-de-açúcar.

Os setores sul, sudeste, leste e nordeste evidenciam um grande crescimento urbano e onde já era fraca a presença arbórea, neste período quase desapareceu por completamente, mas nas áreas íngremes de fundo de vales, ainda foi possível delimitar a presença de verde com muitas árvores, certamente essas áreas eram de APPs.

A cobertura vegetal total deste período somou $12.703 \mathrm{mil} \mathrm{m}^{2}$, sendo este o segundo período de menor presença de cobertura vegetal em Piracicaba.

Na região central houve um preenchimento urbano da quase totalidade da área. Na região leste surgiram os bairros do Jardim Abaeté, Dois Córregos, Pompéia, Santa Rita, Unileste e Monte Alegre. Na região sul houve o preenchimento do bairro da Paulicéia, Bairro Verde Jardim Caxambu e Monte Líbano. Na região oeste surgiu a Vila Cristina, Jardim Itapuã, Jardim Planalto, São Jorge, Morato, Glebas Califórnia, Jupiá e Ondas. Na região norte: Vila Fátima, Algodoal, Vila Industrial e Vila Sônia, com um crescimento considerável do bairro Santa Terezinha.

A figura 10 mostra a cobertura vegetal de 1978, evidenciando como ela diminuiu em comparação ao período de 1962, e o limite urbano de 1940, 1962 e 1978, mostrando o direcionamento da expansão urbana. A direção vetorial do crescimento urbano de Piracicaba se localizou para o noroeste até 1978, porém esse direcionamento encontra outro concorrente a partir dos anos 80 . 


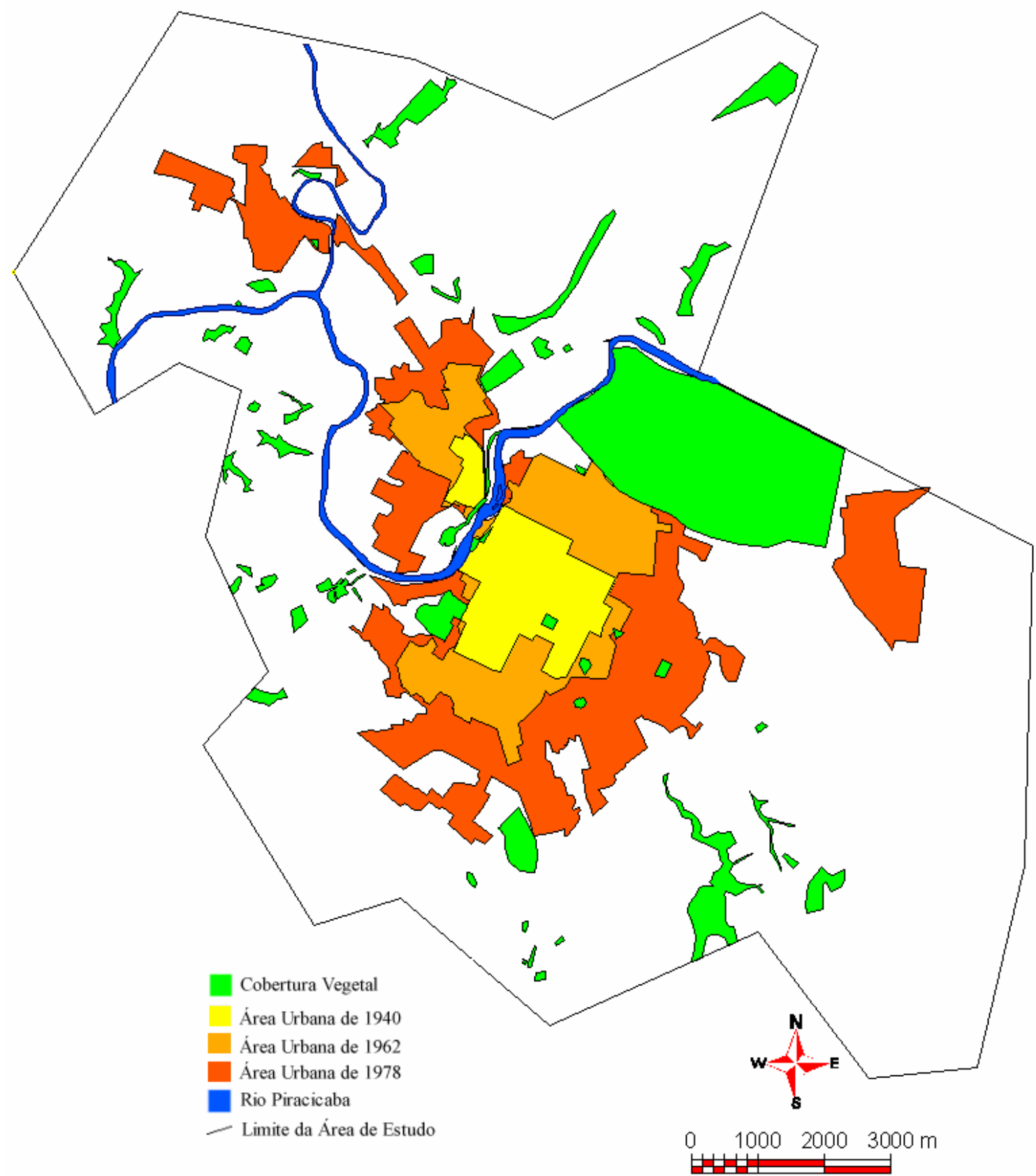

Figura 10- Perímetros Urbanos de 1940 a 1978 e Áreas de Cobertura Vegetal de 1978 


\subsection{Período de 1995}

Segundo o Plano Diretor de Desenvolvimento Urbano de Piracicaba de 1991, o crescimento da cidade se projetaria em duas direções ou vetores ao mesmo tempo, que seriam os vetores nas direções Noroeste e Sudeste. Porém, neste mesmo plano foi verificado os vetores de expansão em: Vetor Norte, Vetor Nordeste, Vetor Leste, Vetor Sudeste, Vetor Sul, Vetor Sudoeste, Vetor Oeste e Vetor Noroeste.

A tabela 4 mostra o direcionamento proposto para cada vetor de expansão urbana, tomando como referencial o centro da cidade.

Tabela 4. Vetores de Expansão Urbanos, propostos pelo Plano Diretor de 1991

Vetor Norte

Vetor Nordeste
Compreende a região entre o Ribeirão Guamium até a SP 127 (Rio Claro). Inicia após a área da Estação Experimental de cana de Piracicaba, a qual oferece barreira à interligação com a malha urbana. A existência da Usina Modelo também representa impedimento ao maior adensamento. A topografia é regular e a maior parte do solo é ocupada com plantações de cana.

Este setor está inserido entre as rodovias de acesso aos municípios de Rio Claro (SP 127) e Limeira (SP 147). Possui condições territoriais médias, estando a montante do rio Piracicaba, o que agrava a questão ambiental. As terras são de primeira qualidade para a agricultura. Quanto à questão de infra-estrutura para a urbanização, a região dispõe de redes básicas, principalmente abastecimento de água, encarecendo custos. O desenvolvimento deste vetor é viável a longo prazo. 
Tabela 4. Vetores de Expansão Urbanos, propostos pelo Plano Diretor de 1991

\begin{tabular}{|c|c|}
\hline Vetor Leste & $\begin{array}{l}\text { Constitui a região delimitada pela ESALQ, Rio Piracicaba e } \\
\text { antiga SP 304. A Unidade Industrial Leste (UNILESTE) está } \\
\text { inserida neste vetor, bem como a Caterpillar. Há infra-estrutura } \\
\text { razoável em virtude das indústrias, sendo a áreas servida por } \\
\text { rodovias e pelo Anel Viário. As terras disponíveis estão } \\
\text { ocupadas com canaviais, sendo portando de boa qualidade para } \\
\text { a agricultura. O Ribeirão Piracicamirim delimita a região. }\end{array}$ \\
\hline Vetor Sudeste & $\begin{array}{l}\text { Compreende a região urbana que tem início no bairro } \\
\text { Piracicamirim, na bifurcação das avenidas Pompéia e Rio das } \\
\text { Pedras, indo até o Parque Cecap e o loteamento Santa Rita. É o } \\
\text { vetor mais favorável quanto a adequação do território, } \\
\text { apresentando topografia predominantemente suave. A questão } \\
\text { ambiental pode ser controlada, pois ainda não se verifica } \\
\text { grandes impactos nos mananciais afluentes do Ribeirão } \\
\text { Piracicamirim. }\end{array}$ \\
\hline Vetor Sul & $\begin{array}{l}\text { Região da cidade que se desenvolveu muito pouco nos últimos } \\
\text { vinte anos, talvez em virtude da pequena malha viária, } \\
\text { constituída de estradas rurais. Já houve tentativa de } \\
\text { prolongamento da avenida Água Branca até o CEASA. Há } \\
\text { dificuldade para extensão da infra-estrutura. As terras são boas } \\
\text { para a agricultura, sendo utilizadas com cultura de cana. A } \\
\text { topografia é suave. }\end{array}$ \\
\hline
\end{tabular}


Tabela 4. Vetores de Expansão Urbanos, propostos pelo Plano Diretor de 1991

\begin{tabular}{|c|c|}
\hline Vetor Sudoeste & $\begin{array}{l}\text { Situa-se em região de grande crescimento urbano, que se deu } \\
\text { provavelmente pela inaptidão das terras ao cultivo da cana. } \\
\text { Apresenta acentuada declividade topográfica. As terras, ainda } \\
\text { livres, embora apresentem relevo médio, são ocupadas por } \\
\text { pequenas propriedades, sítios e chácaras de recreio. A } \\
\text { qualidade ambiental é bastante afetada. O Ribeirão do Enxofre } \\
\text { que corta a região é o mais poluído da cidade. Quanto à } \\
\text { moradia/emprego, é o vetor com piores condições, quer pelas } \\
\text { dificuldades viárias, quer pela situação oposta aos centros } \\
\text { geradores de emprego. }\end{array}$ \\
\hline Vetor Oeste & $\begin{array}{l}\text { Região delimitada pelo Rio Piracicaba e a estrada do Bongue. } \\
\text { É o vetor com relevo mais acentuado, sendo ocupado por sítios } \\
\text { com produção diversificada e chácaras de recreio localizadas } \\
\text { às margens do rio. O sistema viário é precário e os } \\
\text { investimentos em infra-estrutura são consideravelmente altos. }\end{array}$ \\
\hline Vetor Noroeste & $\begin{array}{l}\text { Corresponde ao Distrito de Santa Terezinha de Piracicaba, } \\
\text { estando limitado a leste pelo Rio Piracicaba e ao norte pelo Tio } \\
\text { Corumbataí. O vetor apresentou crescimento razoável nos } \\
\text { últimos } 20 \text { anos. O aspecto mais desfavorável diz respeito às } \\
\text { condições ambientais, dada a localização da área entre os rios } \\
\text { Piracicaba e Corumbataí, principalmente este último, que serve } \\
\text { ao abastecimento da cidade. A relação moradia/emprego } \\
\text { também se mostra favorável, pela proximidade com } \\
\text { importantes indústrias, inclusive no próprio bairro e ao longo } \\
\text { do eixo viário do vetor, que apresenta grande concentração } \\
\text { industrial. }\end{array}$ \\
\hline
\end{tabular}

Fonte: POMPERMAYER,1998. 
Piracicaba adentrou os anos 90 com grande crescimento e desenvolvimento econômico e urbano. No censo de 1991 registrou-se uma população de 283.833 habitantes, sendo que 269.961hab/urbano e 13.872 hab/rural. Para o ano de 1995 houve uma estimativa de 297.890 habitantes.

A figura 11 mostra o perímetro urbano em 1995 e as áreas de cobertura vegetal neste período. O desenvolvimento urbano entre 1978 e 1995 acabou refletindo no aspecto ambiental natural e o mapa evidenciou as áreas urbanas que englobaram áreas de verde natural e algumas frações desapareceram, proporcionando ao ambiente urbano pouca ou nenhuma condição de verde natural. 


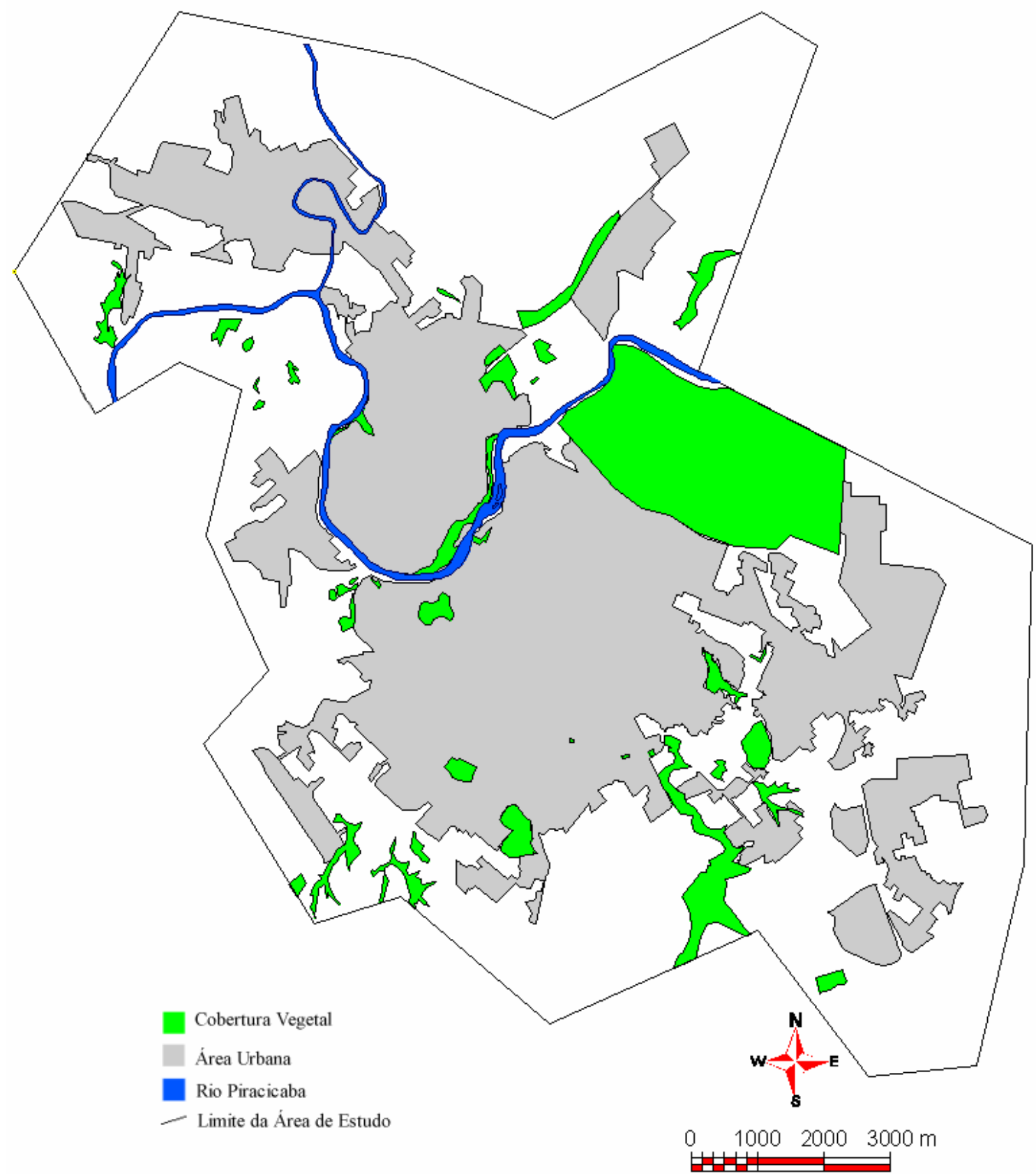

Figura 11- Perímetro Urbano e Cobertura Vegetal de 1995 
Na porção oeste e norte houve um recuo nas áreas da cobertura vegetal e houve um considerável avanço urbano, principalmente na direção noroeste e parte central da Vila Rezende e Nova Piracicaba.

Outros setores que apresentaram um grande crescimento urbano foram os do sul, sudeste, leste e nordeste, já citados na tabela 4. Um dos fatos que pode ser relacionado aí foi a implantação do setor industrial a leste da cidade. Praticamente desapareceu o verde que existia nestes locais, porém ainda foi possível observar uma mancha de cobertura vegetal a sudeste.

O Parque do Mirante e o Engenho Central mostraram um crescimento de sua mata ciliar e esta parece ter se expandido em ambas margens do leito do rio, mas especialmente à margem direta.

A chácara Nazareth apresentou uma perda no tamanho de sua cobertura vegetal e foi totalmente circulada pela área urbana, parte de sua área territorial foi loteada. Sua área de cobertura vegetal, neste período registrou $151 \mathrm{mil} \mathrm{m}^{2}$. O parque da Esalq teve um crescimento em sua cobertura verde ao noroeste e apresentou 7.892mil $\mathrm{m}^{2}$. Houve avanço da infra-estrutura urbana sobre a área de cobertura vegetal da Esalq na região sudoeste. Ao norte houve uma conservação em relação ao período de 1978, porém frações menores da cobertura verde desapareceram com a chegada da infraestrutura urbana (Bairro Santa Rosa).

Em 1995 foi registrado um total de cobertura vegetal de $12.544 \mathrm{mil} \mathrm{m}^{2}$. Este foi o período de menor presença de áreas naturais da cobertura vegetal em Piracicaba.

Com a verticalização da área central houve um esvaziamento populacional de imóveis neste local e foi também um período onde ocorreu a eventual transferência de moradores para o bairro da Nova Piracicaba e condomínios residenciais que surgiram a partir deste período com maior ênfase nos arredores da cidade. Surgiram novos bairros. Na região sul: Água Branca e parte do bairro Campestre. A região leste: Jardim São Francisco, Cecap, Taquaral, Monte Alegre e Conceição. Na região oeste: intensificam as 
construções no bairro Jupiá, Ondas e surge o bairro Ondinhas. Na região norte: Santa Rosa, Guamium, Mário Dedini, Parque Piracicaba e Vale do Sol.

A figura 12 mostra as áreas de cobertura vegetal de 1995 e os perímetros urbanos em expansão entre 1940, 1962, 1978 e 1995. 


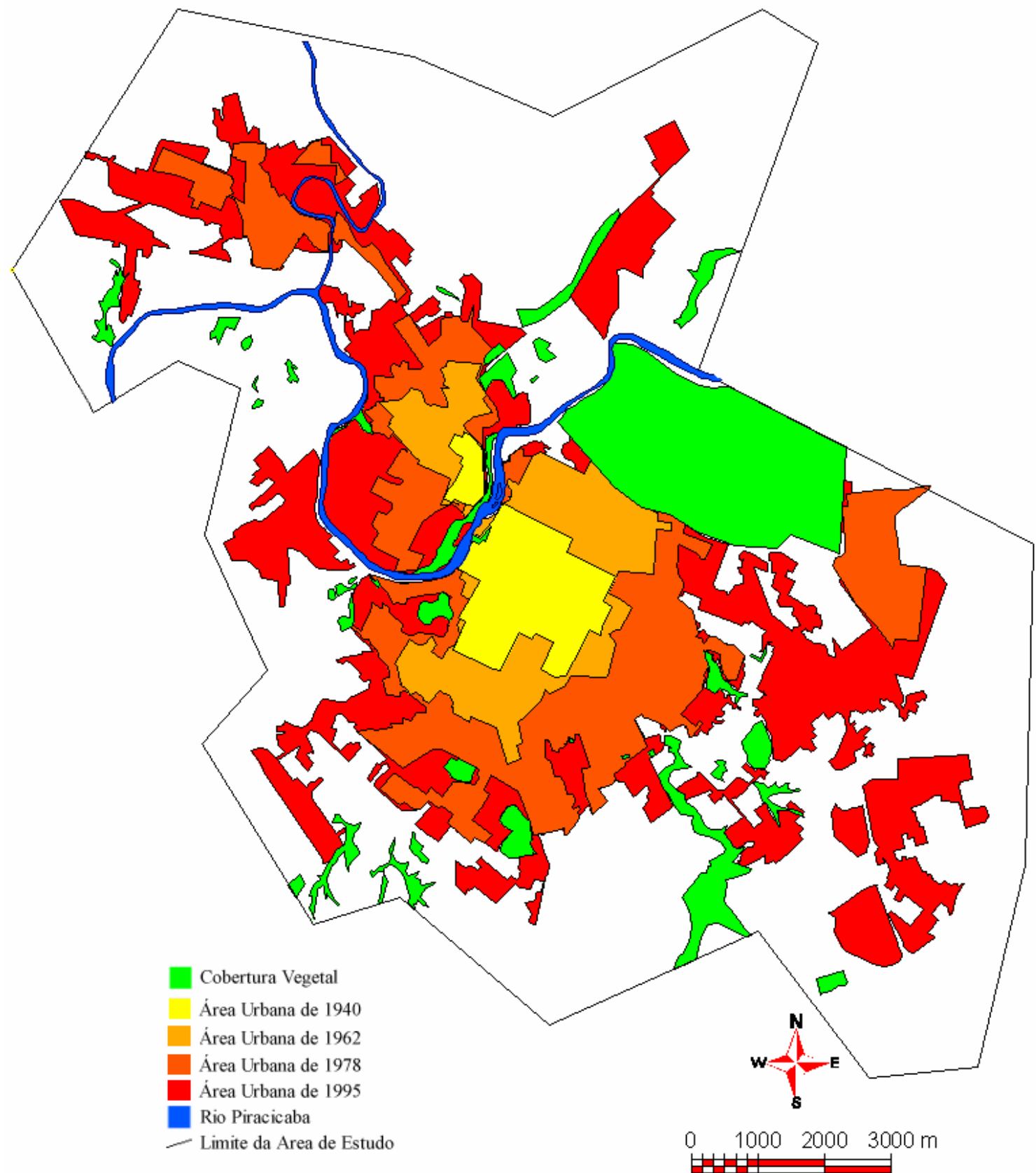

Figura 12- Perímetros Urbanos de 1940 a 1995 e Áreas de Cobertura Vegetal de 1995 


\subsection{Período de 2000}

Piracicaba tem muitos desafios pela frente. As relações capitalistas aceleraram o crescimento urbano e este vai ganhando novas formas e novos contornos (POMPERMAYER,1998). Assim como foi previsto pelo Plano Diretor de 1991 a cidade de Piracicaba se expandiu em duas direções principais, a Noroeste e a Sudeste. A Figura 13 mostra estes vetores e também as áreas de cobertura vegetal em 2000. E, em apenas cinco anos a cobertura vegetal apresentou um aumento em relação ao período de 1995.

O censo realizado em 2000 registrou um total de 328.312 habitantes, sendo que 316.518 hab/urbano e 11.794 hab/rural. A população apresentou, segundo dados do IBGE, um crescimento populacional de $116 \%$ entre 1970 e 2000. 


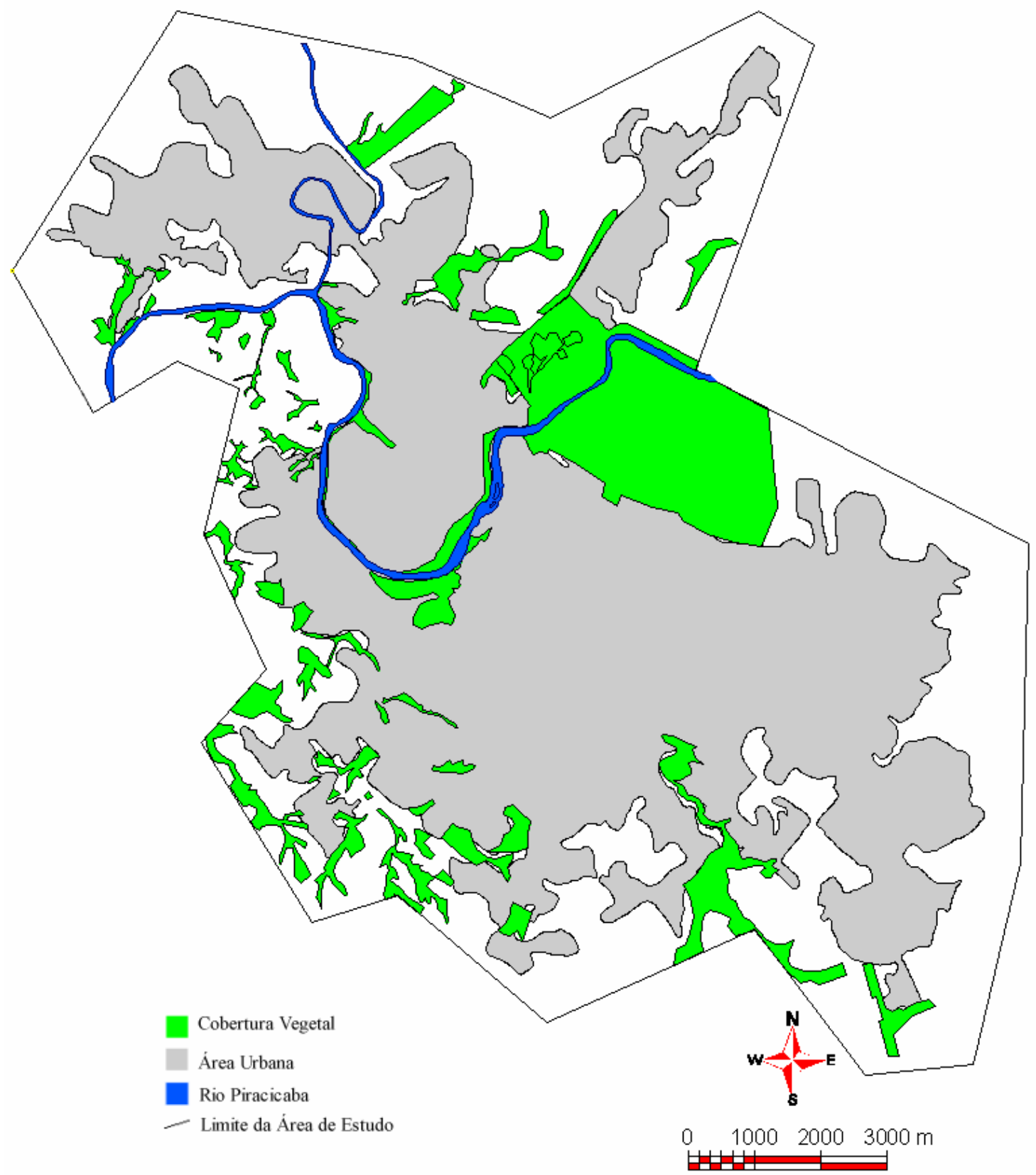

Figura 13- Perímetro Urbano e Áreas de Cobertura Vegetal de 2000

Em cinco anos a cobertura vegetal apresentou um aumento em relação ao período anterior de 1995. O principal fator para o crescimento da cobertura vegetal dentro e no entorno da cidade entre 1995 e 2000 foi o respeito pela legislação sobre as Áreas de Proteção Permanentes (APPs), pois os locais de maior recuperação foram áreas 
de matas ciliares. Não houve por parte da Secretaria Municipal do Meio Ambiente nenhum projeto específico para explicar o relativo aumento da cobertura vegetal , mas o projeto do comitê de bacias (Capivari, Jundiaí e Piracicaba), que existe na região, proporcionou o replantio de várias mudas de árvores ao longo de afluentes do Rio Piracicaba e Corumbataí. Apesar desta ação, a resposta mais viável para o aumento da cobertura vegetal seja realmente o de que as áreas de APPs foram respeitadas e conseguiram em um espaço relativamente pequeno se reconstituir, elevando assim o índice de cobertura vegetal dentro e na região e principalmente no entorno da cidade. Há por parte da legislação municipal um incentivo para donos de áreas de APPs e que beneficia em $50 \%$ na cobrança do imposto, mas existe uma discussão para que o desconto seja cada vez maior à medida que a área de preservação permanente cresça.

A figura 13 mostrou que o parque da Esalq foi invadido pela infraestrutura urbana nas direções sudeste, oeste, noroeste e parte norte, porém a sua cobertura vegetal permaneceu expressiva, apresentando uma área de $8.697 \mathrm{mil} \mathrm{m}^{2}$.

A chácara Nazareth apresentou uma área de cobertura vegetal maior do que o período de 1995 , apesar dos loteamentos realizados e registrou $605 \mathrm{mil} \mathrm{m}^{2}$, com certeza esse aumento foi proveniente a regeneração natural e aumento das copas das árvores. Os parques do Mirante/Engenho Central apresentaram áreas de cobertura vegetal aumentadas também, e esse fato não diz respeito ao plantio de novas árvores, mas sim do crescimento das copas das árvores e de uma regeneração natural de outras espécies no local, assim como aconteceu na Chácara Nazareth.

A porção noroeste, oeste, sudoeste e sul da cidade refloresceram em manchas verdes, foram às áreas de mata ciliares já mencionadas. A região leste foi a única a registrar falta da cobertura vegetal em função da grande expansão urbana que houve nesta direção (Unileste).

No período de 2000 foi registrado um total de cobertura vegetal de $18.301 \mathrm{mil} \mathrm{m}^{2}$. Este foi o melhor período de presença de cobertura vegetal para a cidade de Piracicaba. 
A figura 14 mostra os perímetros urbanos de 1940, 1962, 1978, 1995 e 2000, juntamente com as áreas de cobertura vegetal de 2000.

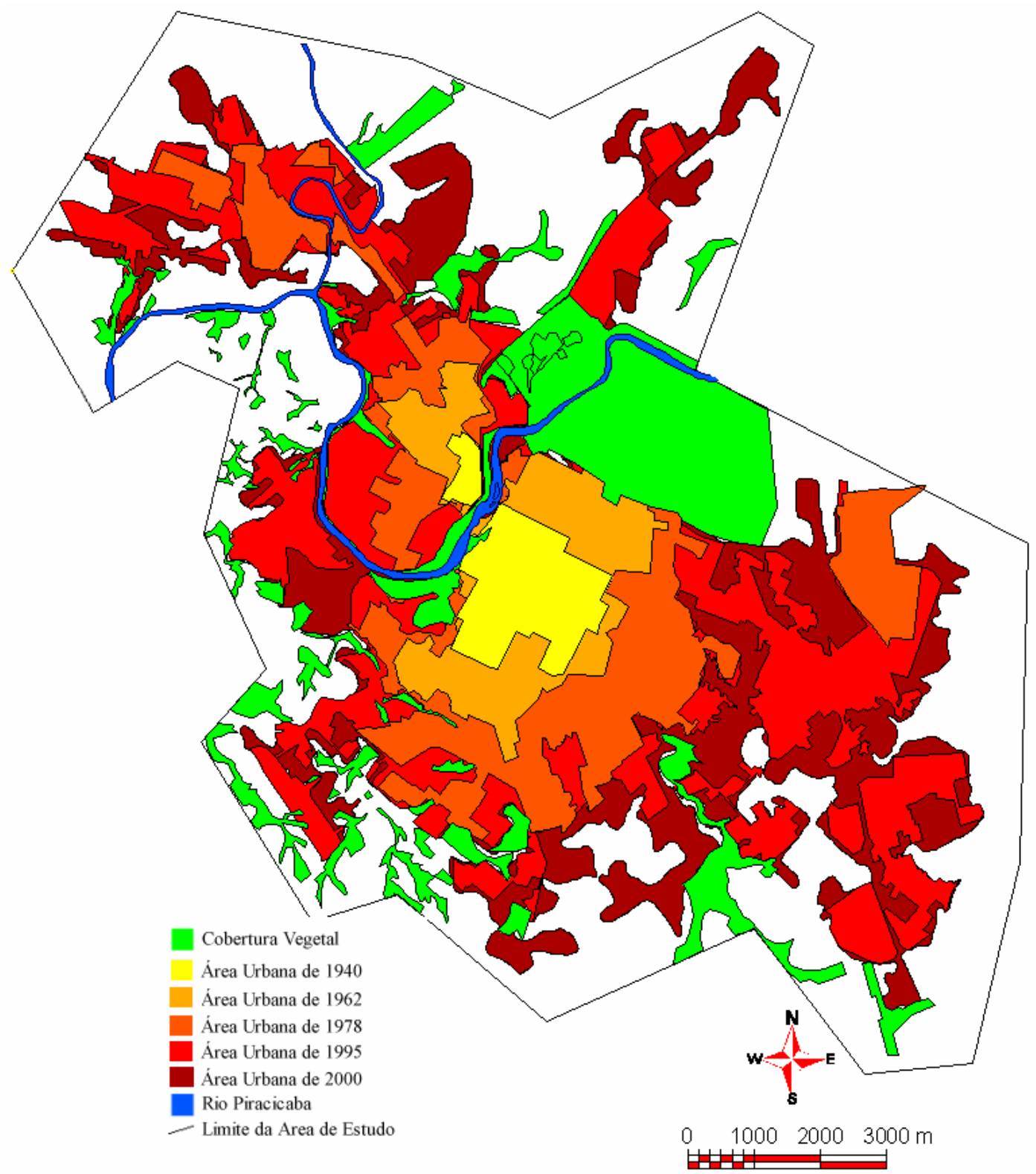

Figura 14- Perímetros Urbanos de 19940 a 2000 e Áreas de Cobertura Vegetal de 2000 


\subsection{Análise cartográfica do período de 1940 a 2000}

\subsubsection{Coberturas vegetais de 1940 a 2000: destaque para 1940}

A figura 15 evidencia toda cobertura vegetal que apareceu em maiores tamanhos nos períodos de 1940 a 2000. A cor amarela representa as frações verdes de 1940, contrastando com as demais áreas de cobertura vegetal dos outros períodos, onde a cor verde escura até a verde clara, revela as frações verdes dos períodos mais distantes para o mais recente.

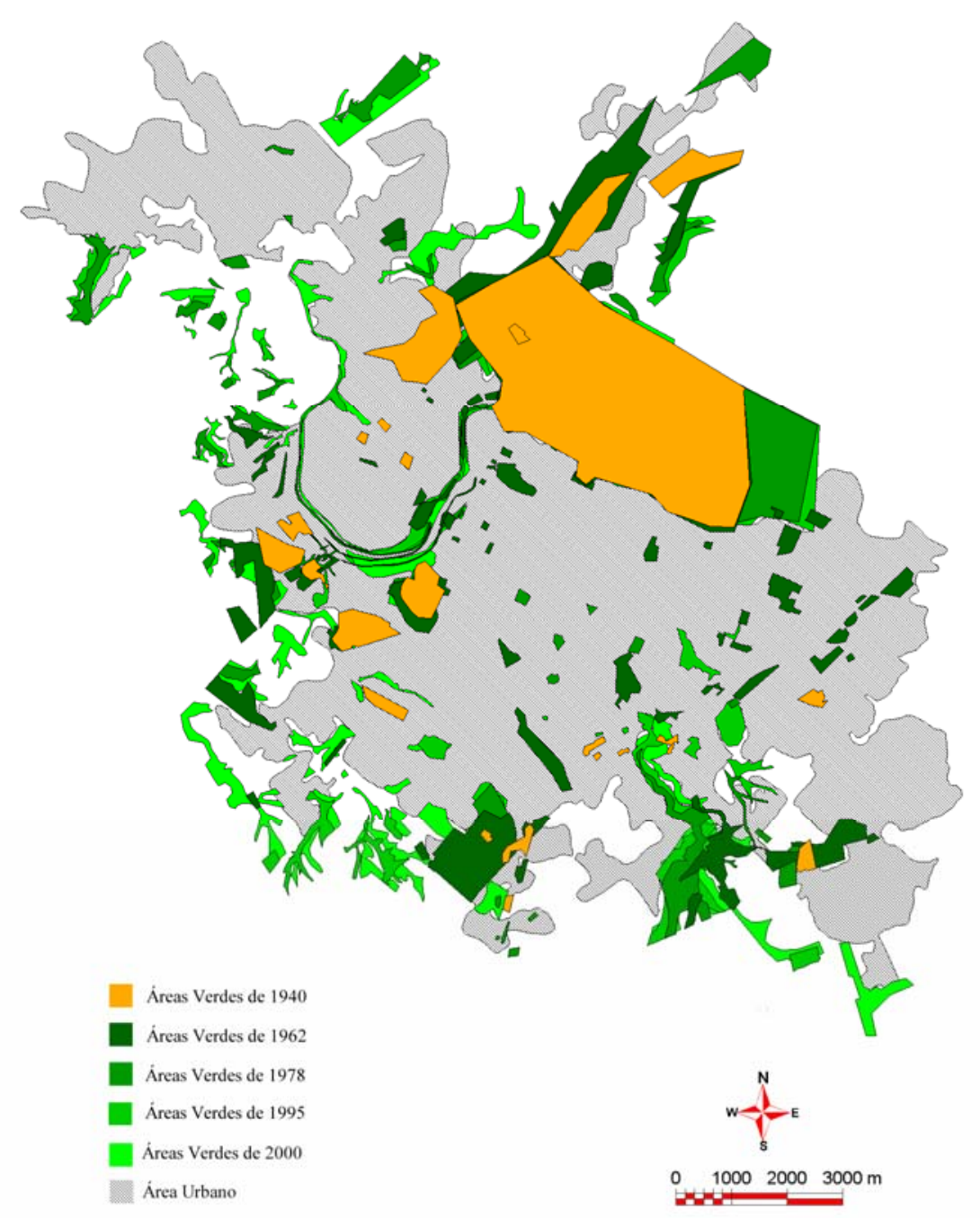

Figura 15- Áreas Verdes de 1940 a 2000 e Área Urbana de 2000 
Percebe-se que a área de cobertura vegetal aumentou depois de 1940, tanto em tamanho quanto em número de frações. Nas regiões noroeste e sudoeste apareceram ramificações de verdes que não existiam na década de 40. A Esalq apresentou uma perda de sua cobertura natural a noroeste, mas houve uma expansão de sua cobertura vegetal na direção leste.

Novas áreas de recobrimento vegetal surgiram no entorno da cidade durante 1940 a 2000, principalmente a leste e sul (Figura 15). Mesmo dentro da mancha urbana foi possível evidenciar o surgimento de praças e locais vazios com aumento de verde na porção central da cidade. Houve uma preservação de certos locais verdes desde 1940 até o ano 2000 e em alguns desses lugares houve até uma expansão e depois uma retração, como por exemplo a Chácara Nazareth e o Parque da Esalq.

\subsubsection{Coberturas vegetais de 1940 a 2000: destaque para 2000}

Na figura 16 foi invertida a cor em relação à figura 15 e foi colocado em destaques às coberturas verdes de 2000 que estão na cor amarela e as outras áreas em ordem decrescente de tonalidades de verdes claro ao escuro. Observa-se que a cobertura vegetal atual é o mais abundante em relação aos demais períodos, porém, algumas áreas desapareceram, principalmente dentro da mancha urbana. 


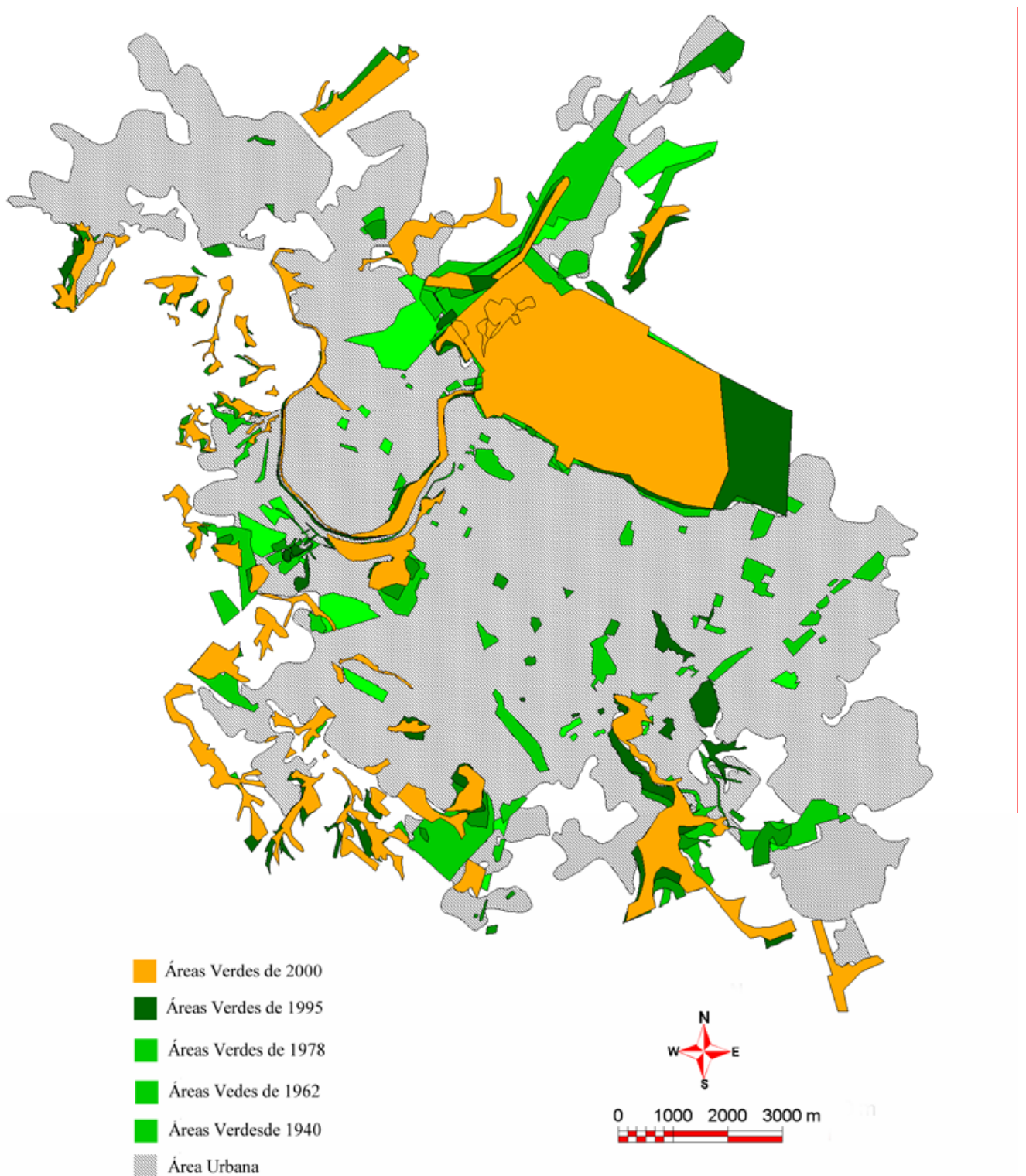

Figura 16- Áreas Verdes de 2000 a 1940 e Perímetro Urbano de 2000

A norte, nordeste e leste, frações verdes desapareceram com o adensamento urbano. A área da cobertura vegetal da chácara Nazareth diminuiu, mas houve uma expansão de verde a noroeste da chácara, rumo a área de lazer da prefeitura. A oeste da prefeitura houve uma relativa perda entre 1940 e 2000 e as poucas frações que sobreviveram se separaram, formando frações pequenas de verde. Ao sul 
desapareceram matas ciliares, mas uma pequena fração verde conseguiu ser preservada, sendo hoje a mais significativa dessa região. Ao sudoeste, surgiram manchas mais densas com presença de copa arbórea mais significativa em locais íngremes, certamente áreas de APPs. Ao sul a existência da cobertura vegetal parece ser remanescente de épocas mais abundantes e que no presente período sofreu perda. Os mosaicos dos períodos anteriores realmente comprovaram que nestes locais havia manchas arbóreas mais significativas.

Com o avanço da cidade na direção sudeste, o verde natural dessa região desapareceu. A cidade expandiu englobando e fazendo desaparecer áreas naturais e ao se tornar área urbana, o espaço transformado ficou desprovido de áreas verdes naturais e os novos bairros não projetaram espaços para essa finalidade, resultando em uma região desprovida de verde e espaços ambientais urbanos.

\subsubsection{Evolução da área urbana consolidada de Piracicaba entre 1940 a 2000}

A figura 17 mostra os vetores de expansão urbana da cidade de Piracicaba durante o período de 1940 a 2000. Entre 1940 e 1962 a expansão urbana aconteceu de forma circular ao ponto referencial central. Entre 1962 e 1978 o direcionamento foi maior no sentido noroeste, fato ocasionado pela instalação de indústria ao longo do sistema viário dessa região. Entre 1978 e 1995, o vetor de expansão continua em sentido noroeste, mas também se expande em sentido sudeste, pois nos anos 90 houve a criação do setor industrial na região sudeste. Os dois pólos de expansão que mais se destacaram nos períodos de 1940 e 2000 foram exatamente o eixo noroeste e sudeste. Entre 1995 e 2000 a expansão urbana acompanhou o direcionamento dos dois eixos e esse fato já havia sido previsto pelo Plano Diretor da Cidade em 1991. 


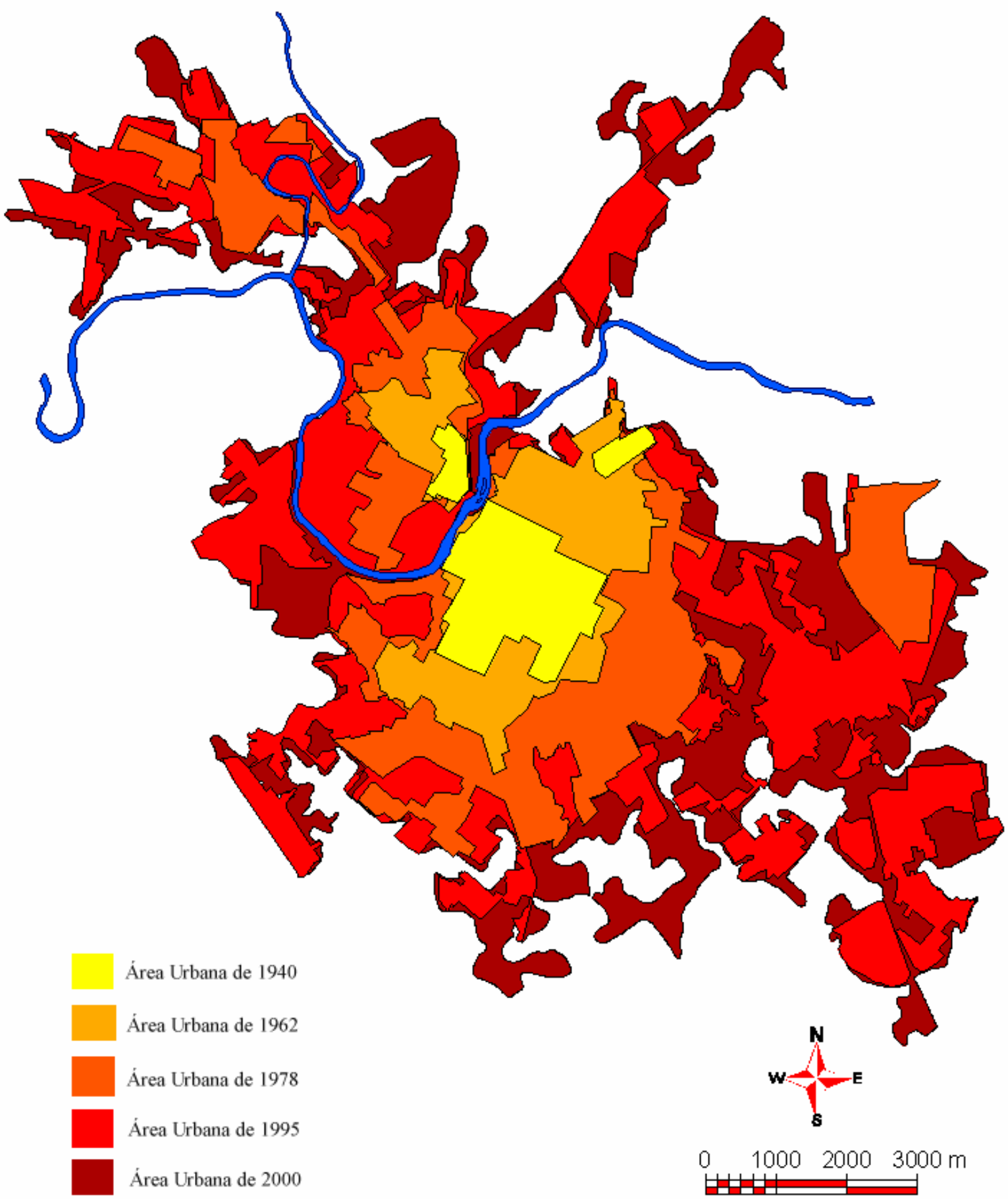

Figura 17- Evolução urbana de Piracicaba entre 1940 a 2000 
4.6.4 Evolução do Perímetro urbano e da cobertura vegetal de Piracicaba entre 1940 e 2000

A figura 18 mostra a evolução dos perímetros urbanos e dos polígonos da cobertura vegetal entre 1940 a 2000 com a aproximação dos mapas para facilitar a comparação entre os períodos. 


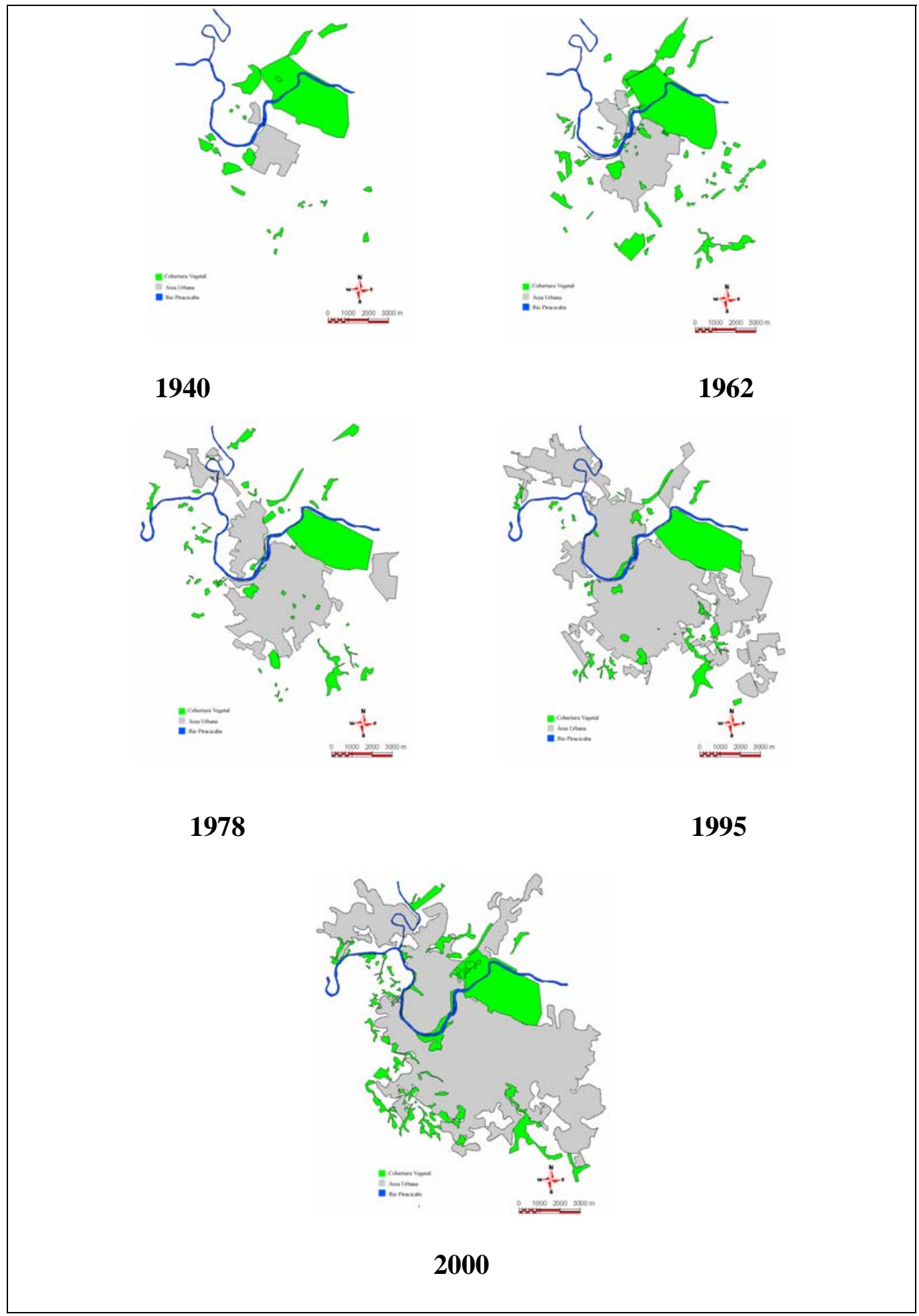

Figura 18- Evolução do perímetro urbano e da cobertura vegetal de Piracicaba entre 1940 e 2000 


\subsection{Análise quantitativa do período de 1940 a 2000}

Através dos dados formulados e dos mapas criados, foi possível a elaboração de algumas tabelas para melhor compreensão das conclusões e sugestões que serão aqui propostas .

\subsubsection{Surgimento dos bairros}

A tabela 5 organizou os períodos de surgimento dos bairros que hoje compõem a cidade de Piracicaba. Com base na figura 3 (Mapa de zoneamento urbano de Piracicaba) e na figura 17 que mostrou a expansão urbana nos períodos de 1940, 1962, 1978, 1995 e 2000, evidenciamos uma ordem para o surgimento de cada bairro.

Tabela 5. Surgimentos dos bairros

\begin{tabular}{l|l|l}
\hline ANO & $\begin{array}{r}\text { QUANTIDADE } \\
\text { DE BAIRROS }\end{array}$ & NOMES DOS BAIRROS \\
& \multicolumn{1}{|c|}{08} & São Dimas \\
& São Judas & Cidade Jardim \\
& Cidade Alta \\
& Clube de Campo \\
& Centro & \\
& Vila Rezende & Parte nordeste da Nova \\
& Piracicaba
\end{tabular}


Tabela 5. Surgimentos dos bairros

\begin{tabular}{|c|c|c|}
\hline 1962 & 25 & $\begin{array}{l}\text { Nho Quim } \\
\text { Monumento } \\
\text { Piracicamirim } \\
\text { Nova América } \\
\text { Jardim Elite } \\
\text { Higienópolis } \\
\text { Paulista } \\
\text { Parte da Paulicéia } \\
\text { Castelinho } \\
\text { Jaraguá } \\
\text { Parte do Areião } \\
\text { Parte do Jardim Primavera } \\
\text { Vila Monteiro } \\
\text { Vila Independência } \\
\text { Parte Leste e Sul da Nova } \\
\text { Piracicaba }\end{array}$ \\
\hline 1978 & 46 & $\begin{array}{l}\text { Jardim Abaeté } \\
\text { Dois Córregos } \\
\text { Pompéia } \\
\text { Bairro Verde } \\
\text { Jardim Planalto } \\
\text { Jardim Caxambu } \\
\text { Monte Líbano } \\
\text { Vila Cristina } \\
\text { Jardim Itapuã } \\
\text { São Jorge } \\
\text { Morato } \\
\text { Glebas Califórnia } \\
\text { Jupiá } \\
\text { Ondas } \\
\text { Vila Fátima } \\
\text { Algodoal } \\
\text { Vila Industrial } \\
\text { Santa Terezinha } \\
\text { Vila Sônia } \\
\text { Monte Líbano } \\
\text { Santa Rita } \\
\text { Preenchimento total da Nova } \\
\text { Piracicaba }\end{array}$ \\
\hline
\end{tabular}


Tabela 5. Surgimentos dos bairros

\begin{tabular}{ll}
\hline 60 & Água Branca \\
& Bairro Campestre \\
& Jardim São Francisco \\
& CECAP \\
& Taquaral \\
& Conceição \\
& Ondinhas \\
& Santa Rosa \\
& Guamium \\
& Mário Dedini \\
& Parque Piracicaba \\
& Novo Horizonte \\
& Vale do Sol \\
& Monte Alegre \\
& Unileste \\
& Preenchimento do bairro Jupiá \\
& Preenchimento do bairro \\
& Ondas \\
& Preenchimento dos bairros \\
& localizados na direção \\
& Noroeste e Sudeste da cidade \\
\hline
\end{tabular}

A organização do período de surgimento de cada bairro foi elaborada através da observação das imagens criadas neste trabalho e de acordo com o registro da evolução por década de loteamentos da Prefeitura (2002), foi possível organizar os nomes em uma ordem cronológica. 


\subsubsection{Perímetros Urbanos de Piracicaba}

A tabela 6 mostra a organização das datas de oficialização dos perímetros urbanos da cidade de Piracicaba ao longo de sua história.

Tabela 6. Histórico da oficialização dos perímetros urbanos de Piracicaba

\begin{tabular}{|c|c|c|}
\hline $\begin{array}{l}\text { Classificação do } \\
\text { Perímetro Urbano }\end{array}$ & Data da Oficialização & Ata de Registro \\
\hline $1^{\circ}$ & $16 / 02 / 1831$ & $\begin{array}{l}\text { Ata da Câmara Municipal de Vila } \\
\text { Nova da Constituição }\end{array}$ \\
\hline $2^{\circ}$ & 15/03/1839 & Idem \\
\hline $3^{\circ}$ & 24/06/1843 & Idem \\
\hline $4^{\circ}$ & $12 / 10 / 1844$ & Idem \\
\hline $5^{\circ}$ & 04/06/1845 & Idem \\
\hline $6^{\circ}$ & 23/10/1858 & $\begin{array}{l}\text { Ata da Câmara Municipal da Cidade } \\
\text { de Constituição }\end{array}$ \\
\hline $7^{\circ}$ & 03/11/1896 & Idem \\
\hline $8^{\circ}$ & $15 / 06 / 1914$ & Idem \\
\hline $9^{\circ}$ & 21/03/1921 & Idem \\
\hline $10^{\circ}$ & 23/11/1939 & Idem \\
\hline $11^{\circ}$ & 1956 & $\begin{array}{l}\text { Ata da Câmara Municipal da Cidade } \\
\text { de Piracicaba }\end{array}$ \\
\hline $12^{\circ}$ & 1969 & Idem \\
\hline $13^{\circ}$ & 1975 & Idem \\
\hline $14^{\circ}$ & 1978 & Idem \\
\hline $15^{\circ}$ & 1982/83 & Idem \\
\hline $16^{\circ}$ & 1989 & Idem \\
\hline $17^{\circ}$ & 1999 & Idem \\
\hline $18^{\circ}$ & 2003 & Idem \\
\hline
\end{tabular}

Fonte: POMPERMAYER,1998 e Prefeitura Municipal de Piracicaba, 2003

Os perímetros urbanos delimitados neste trabalho corresponderam aos perímetros oficiais mais próximos das datas aqui estudadas. 


\subsubsection{Cobertura vegetal por habitante}

A tabela 7 evidenciou a relação entre a cobertura vegetal por habitante urbano em cada período. O índice foi calculado com base na delimitação dos polígonos da cobertura vegetal, criados neste trabalho, que deve como referência o espaço territorial um pouco maior do que o perímetro urbano de 2000.

Tabela 7. Cobertura vegetal por habitante

\begin{tabular}{cccccc}
\hline Período & $\begin{array}{c}\text { População } \\
\text { Total }\end{array}$ & $\begin{array}{c}\text { População } \\
\text { Urbana }\end{array}$ & $\begin{array}{c}\text { População } \\
\text { Rural }\end{array}$ & $\begin{array}{c}\text { Total da Cobertura } \\
\text { Vegetal dos } \\
\text { Polígonos }\end{array}$ & $\begin{array}{c}\text { Cobertura } \\
\text { Vegetal por } \\
\text { Habitante } \\
\text { Urbano }\end{array}$ \\
\hline 1940 & 76.416 & 33.771 & 42.645 & 13.438 & $\mathrm{~m}^{2} / \mathrm{hab}$ \\
1962 & 115.403 & 82.303 & 33.887 & 18.069 & 39,7 \\
1978 & 214.295 & 197.904 & 16.391 & 12.703 & 21,9 \\
1995 & 283.833 & 269.961 & 13.872 & 12.543 & 6,4 \\
2000 & 328.312 & 316.518 & 11.794 & 18.301 & 4,6 \\
\hline
\end{tabular}

Obs: Os dados populacionais de 1995 são estimativos, após dados oficiais de 1991

A soma total da cobertura vegetal, dentro do limite estabelecido para estudo em cada período, foi dividida pela população urbana para obtenção da cobertura vegetal por habitante em $\mathrm{m}^{2}$.

$\mathrm{O}$ resultado mostrou que o melhor índice da cobertura vegetal por habitante foi o de 1940, provavelmente por ter sido o período de menor número de população na área urbana, pois em outros períodos, como por exemplo, o de 1962, as áreas de cobertura vegetal foram em proporções bem maiores do que no período de 1940, porém, como em 1962 houve um grande aumento populacional na área urbana o índice acabou caindo, mas ainda assim, foi o segundo melhor registro da cobertura vegetal em comparação aos demais períodos analisados.

Em 1978 a queda no índice foi brutal de 21,9m²/hab para 6,4m²/hab. A população urbana cresceu consideravelmente em conseqüência da procura de emprego no setor industrial e o crescimento da indústria canavieira na região ocasionou a 
diminuição de áreas de cobertura natural e muitas frações desapareceram com o desmatamento. As áreas da cobertura vegetal do entorno urbano não obtiveram planejamento para serviram de áreas ambientais à medida que a cidade se aproximou.

No período de 1995 aconteceu uma redução nas poucas áreas que sobreviveram do período anterior e as populações urbanas, atraídas pelo emprego, cresceu mais ainda. Esse foi o pior momento para a cobertura vegetal em relação ao número de habitante urbano. $\mathrm{O}$ índice ficou em $4,6 \mathrm{~m}^{2} /$ habitante.

Em cinco anos houve uma relativa melhoria na conservação das antigas áreas de cobertura vegetal. Elas foram deixadas em processo de regeneração natural e houve um aumento no tamanho das copas das árvores. Outro fato que explica esse aumento foi à obediência dos proprietários de APPs (Área de Proteção Permanente) em relação à legislação vigente e essas áreas foram as que mais cresceram entre 1995 e 2000, melhorando o índice da cobertura vegetal por habitante neste período.

\subsubsection{Cobertura vegetal urbana por habitante}

A tabela 8 mostra a relação entre as áreas da cobertura vegetal dentro da área urbana consolidada e o total da população urbana, gerando um indicador em $\mathrm{m}^{2} /$ habitante.

Tabela 8. Área total da cobertura vegetal urbana em relação ao total da população urbana

\begin{tabular}{cccc} 
Ano & $\begin{array}{c}\text { Área Total da } \\
\text { Cobertura Vegetal } \\
\text { Urbana }\end{array}$ & $\begin{array}{c}\text { População Total } \\
\text { Urbana }\end{array}$ & $\begin{array}{c}\text { Área Total da Cobertura Vegetal } \\
\text { X }\end{array}$ \\
\hline mil m ${ }^{2}$ & hab & $\mathrm{m}^{2} / \mathrm{hab}$ \\
1940 & 346 & 33.771 & 10 \\
1962 & 1.431 & 82.303 & 17 \\
1978 & 1.321 & 197.904 & 7 \\
1995 & 2.317 & 269.961 & 9 \\
2000 & 5.376 & 317.374 & 16 \\
\hline
\end{tabular}

Entre as décadas de 40 e 60, a proporção da cobertura vegetal urbana por habitante urbano, correspondia aos índices desejados pelos órgãos ambientais, apesar de 
não se ter ainda neste período uma grande preocupação neste sentido. Após a década de 60, quando intensificou a preocupação ambiental em âmbito mundial, o que se verificou na cobertura vegetal urbana de Piracicaba foi uma diminuição em relação ao aumento populacional, resultado do não aumento dessas áreas e ainda a substituição delas por outras culturas e o próprio avanço da malha urbana sobre esses locais. Entre 1995 e 2000, com a exigência mais intensa sobre o cumprimento das leis ambientais, o índice entre as áreas de cobertura vegetal por habitante urbano apresentou um crescimento.

A partir da década de 80 aumentou a necessidade de se investir no verde dentro da área urbana consolidada e na preservação dos locais naturais do entorno urbano, a fim de possibilitar uma melhoria ambiental.

A figura 19 mostra o crescimento da cobertura vegetal urbana em relação ao total da população urbana entre 1940 e 1962 e como essa relação caiu entre 1960 a 1990, voltando a crescer a partir de 1995 até o período de 2000.

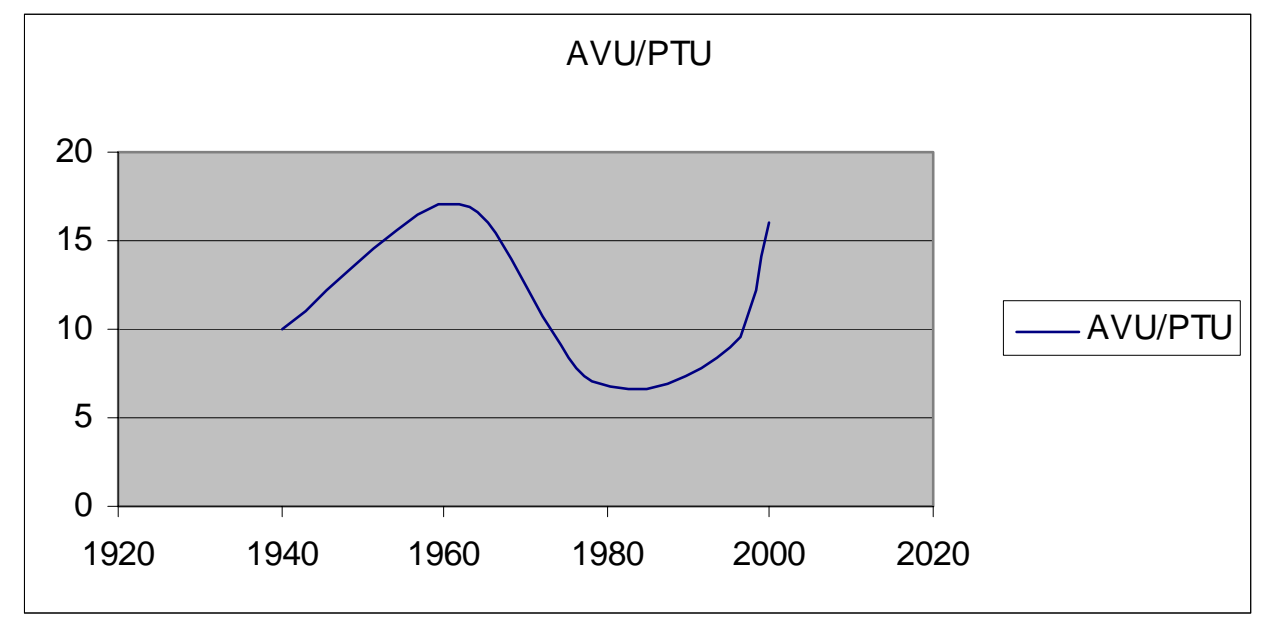

Figura 19- Cobertura vegetal urbana por habitante

\subsection{4 Áreas da cobertura vegetal em relação aos perímetros urbanos}

A tabela 8 foi elaborada a partir das figuras 5, 7, 9, 11 e 13, porém para uma melhor visualização criamos a figura 21 englobando todos os períodos e áreas verdes, ressaltando a localização das frações que foram chamadas na tabela de 1, 2, 3, 4, 
5, 6, 7, 8 ,9 e 10. Esta tabela mostra a distância de dez fragmentos verdes de maiores destaques nos períodos estudados em relação à expansão urbana. O critério usado para realizar a medida das distâncias entre os fragmentos e os limites dos perímetros urbanos em cada período foi através da medida do raio central de cada fragmento em relação ao limite do perímetro. Com essas distâncias foram possíveis visualizar os períodos em que a estrutura urbana englobou algumas áreas naturais e fragmentou outras e também foi possível visualizar o surgimento de novas áreas nos locais periurbanos.

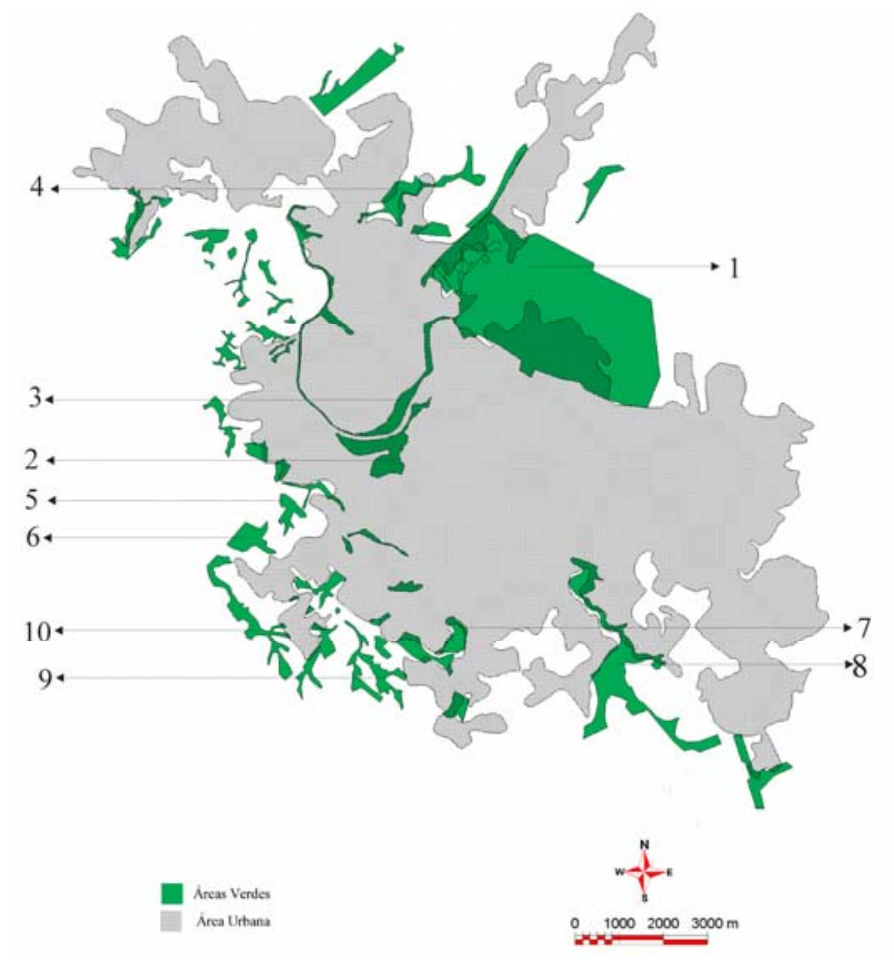

Figura 20- Dez frações da cobertura vegetal

Considerando o local, a direção e os bairros mais próximos das frações das coberturas vegetais destacadas para essa análise, foram criados os seguintes nomes para cada fração:

1- Parque da Esalq

2- Chácara Nazareth

3- Parque do Mirante/Engenho Central

4- Área da UNICAMP

5- Área das Glebas Califórnia
6- Área do Castelinho

7- Área da Paulicéia

8- Área dos Dois Córregos

9- área do Campestre

10- Área do São Jorge 
Tabela 9. Distâncias dos fragmentos da cobertura vegetal em relação ao perímetro urbano

\begin{tabular}{|c|c|c|c|c|c|c|c|c|c|c|}
\hline Fração Verde & 1940 & Área & 1962 & Área & 1978 & Área & 1995 & Área & 2000 & Área \\
\hline & $\mathrm{m}$ & $\mathrm{mil} \mathrm{m}^{2}$ & $\mathrm{~m}$ & $\mathrm{mil} \mathrm{m}^{2}$ & $\mathrm{~m}$ & $\mathrm{mil} \mathrm{m}^{2}$ & $\mathrm{~m}$ & $\mathrm{mil} \mathrm{m}^{2}$ & $\mathrm{~m}$ & $\mathrm{mil} \mathrm{m}^{2}$ \\
\hline Fração 1 & 1,6 & 9.849 & 0 & 9.771 & 0 & 7.626 & $-0,3$ & 7.892 & $-0,2$ & 8.697 \\
\hline Fração 2 & 0 & 357 & $-0,16$ & 496 & $-0,3$ & 87 & $-0,8$ & 150 & $-1,7$ & 774 \\
\hline Fração 3 & - & 0 & 0 & 109 & $-1,3$ & 305 & $-2,5$ & 467 & $-2,6$ & 604 \\
\hline Fração 4 & 0,8 & 463 & 0,6 & 96 & 0 & 78 & $-1,7$ & 65 & $-4,2$ & 534 \\
\hline Fração 5 & 2,9 & 108 & 1,9 & 127 & 0,7 & 87 & 0 & 27 & 0 & 79 \\
\hline Fração 6 & 0,8 & 264 & 0,4 & 416 & *1,3 & 58 & 0 & 58 & 0 & 286 \\
\hline Fração 7 & 2,8 & 95 & 1,3 & 1.301 & 0 & 352 & $-0,5$ & 277 & $-2,1$ & 257 \\
\hline Fração 8 & 3,9 & 93 & 3,6 & 976 & 1,9 & 827 & 0 & 1.126 & $-0,2$ & 1.559 \\
\hline Fração 9 & - & 0 & - & 0 & - & 0 & 0 & 186 & $-0,2$ & 430 \\
\hline Fração 10 & - & 0 & - & 0 & - & 0 & - & 0 & 1,3 & 537 \\
\hline
\end{tabular}

* Em 1978 a fração 6 apresentou uma separação de sua área total e desaparecimento de algumas frações.

** Distância em m do centro do fragmento até o limite do perímetro de cada ano. Distãncia negativa indica que o fragmento foi inserido na área urbana. 
A fração 1 correspondente à área da Esalq, apresentava uma distância do limite do perímetro urbano em 1940. Esse distanciamento praticamente acabou nos anos de 1962, quando o limite do perímetro se encontra com o limite da cobertura vegetal e nos anos posteriores o que se observou foi a chegada da estrutura urbana de forma lenta, mas contínua sobre as áreas naturais da Esalq, ocasionado a diminuição da sua cobertura vegetal durante este processo.

A fração 2 refere-se a área da cobertura vegetal da Chácara Nazareth, que em 1940 fazia limite com o perímetro urbano da cidade. A partir de 1962 o que se observou foi a sobreposição da malha urbana sobre esse fragmento natural e hoje essa área se encontra na região central da cidade.

A fração 3 no período de 1940 não foi visualizada nas interpretações feitas e correspondia a mata ciliar do Rio Piracicaba no local do Parque do Mirante/Engenho Central. Em 1962 a mata se encontra no limite do perímetro urbano e nos anos posteriores a cidade ultrapassa seu limite e isso foi registrado na tabela 8 com sinal negativo nas medidas das distâncias do fragmento em relação ao perímetro urbano.

A fração 4 localizada na região atual do Campus da UNICAMP, estava distante do perímetro urbano em 1940 e a estrutura urbana foi se direcionando para seu encontro e em 1978 essa área de cobertura natural fazia limite com o perímetro urbano. Após 1978, o que se percebeu foi a malha urbana passando sobre essa área natural e reduzindo seu tamanho original.

A fração 5, próxima hoje da região do bairro Glebas da Califórnia, se localizava fora do perímetro urbano até os anos de 1995, quando passou a fazer limite com ele.

A fração 6 da área do bairro Castelinho, era uma mancha densa da cobertura vegetal naquele local, mas com o tempo foi se separando em frações menores com a perda de algumas áreas e até o ano de 1995 estavam fora do perímetro urbano e depois passou a ser uma área que foi sobreposta aos equipamentos urbanos. 
A fração 7, área localizada no bairro da Paulicéia, estava distante do perímetro urbano até 1978 e depois desta data passou a ser integrada à área urbana e registrou uma diminuição na sua área original.

A fração 8 na região dos Dois Córregos, só vai fazer limite com o perímetro urbano em 1995 e depois a estrutura urbana acabou sobrepondo esta área causando perda e diminuição na sua área inicial.

A fração 9, localizada na área do Campestre, surgiu em 1995, fazendo limite com o perímetro urbano.

A fração 10 na área do São Jorge, apareceu em 2000 e ainda se encontra fora do perímetro urbano atual.

Se houver uma atenção para as novas frações verdes que surgiram nos últimos anos nos arredores da cidade, pode-se planejar a chegada urbana de forma a preservar esses locais para melhorar os locais verdes, possibilitando lugares aprazíveis à população e atenuando os fatores poluentes.

\subsection{Características das três áreas de cobertura vegetal que mais se destacaram em Piracicaba entre 1940 e 2000}

As análises dos mosaicos deixaram evidente três áreas que se destacam como locais importantes em relação a cobertura vegetal da cidade de Piracicaba. São eles: A Chácara Nazareth, o Parque do Mirante/Engenho Central e o Parque da Esalq. As três áreas apresentam classificações diferentes quanto ao seu uso e função.

A Chácara Nazareth é propriedade particular da família do Barão de Serra Negra, Francisco José da Conceição, sendo que a visita é restrita. O parque do Mirante com a área do Engenho Central é um local público e bastante freqüentado pela

população local e regional, sendo de responsabilidade municipal o seu cuidado e preservação. O parque da Esalq é um espaço público, pois pertence à Universidade de 
São Paulo. No parque da Esalq existem locais abertos à população e outros de aceso mais restrito, que abrigam as instalações de pesquisas e ensino do Campus.

\subsubsection{Chácara Nazareth}

É uma propriedade da época do café, com características coloniais. Possui antigo terreiro, jardim de programa italiano e grande sede cujo plano foi desenvolvido por Carlos Zanotta. É de propriedade particular e poucos piracicabanos conhecem sua beleza natural ou consideram o seu valor ambiental dentro da estrutura urbana que a circulou.

“Existem nos arredores da chácara uma área remanescente de mata atlântica, um bosque natural de jequitibás e figueiras bravas e seu pomar cultiva a mais completa coleção de frutas brasileiras” (ELIAS,2003). É uma área de aproximadamente $0,9 \mathrm{~km}^{2}$ e conserva o aspecto de sua cobertura vegetal original e que exerce influência benéfica na estrutura ambiental urbana da área central da cidade, amenizando o ruído, reoxigenando o ar, retendo o pó e a fumaça, característica do trânsito que a circunda e proporcionado aos moradores vizinhos um aspecto de paz e tranqüilidade.

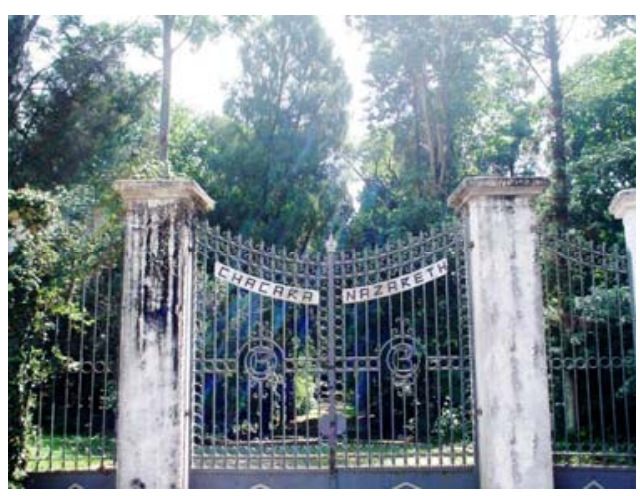

Figura 21- Entrada da Chácara Nazareth

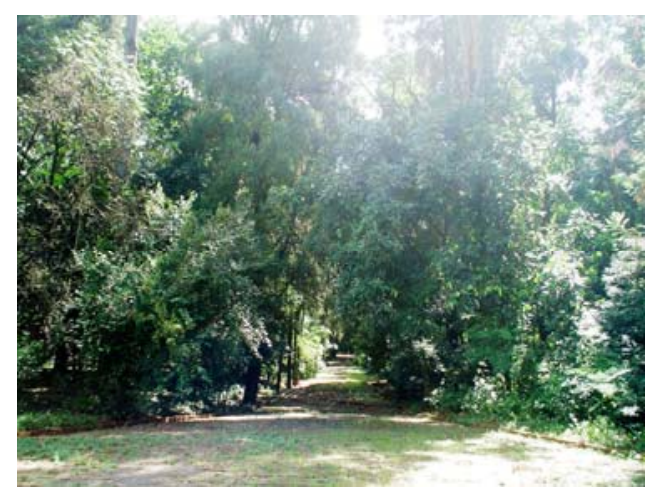

Figura 22- Chácara Nazareth 


\subsubsection{Parque do Mirante/Engenho Central}

O Engenho Central compõe o sítio histórico mais significativo da evolução urbana do município e por isso foi tombado como patrimônio histórico, cultural e ambiental pelo Codepac - Conselho de Defesa do patrimônio Cultural de Piracicaba em 11 de agosto de 1989.

O Engenho Central de Piracicaba foi fundado em janeiro de 1881 pelo Dr. Estevão Ribeiro de Souza Rezende. O Barão de Rezende, que liderava um grupo de empresários piracicabanos e cedeu para a formação da companhia, parte de sua fazenda denominada São Pedro, localizada à margem direita do rio Piracicaba.

A partir da década de 30, muitos engenhos existentes na região desapareceram ou foram englobados pelas usinas. Apesar de sucessivas crises, o Engenho Central ainda foi ampliado nas décadas de 40 e 50, pois o açúcar continuou a exercer papel predominante na economia piracicabana.

A crescente urbanização da vila Rezende e da cidade como um todo acabou por dificultar as atividades operacionais do Engenho Central. Em novembro de 1970 foi vendido para as Usinas Brasileiras de Açúcar S/A - Ubasa, que o manteve em funcionamento até 1974, quando foi desativado radicalmente.

Posteriormente, quase a totalidade das fazendas que compunham a propriedade foi loteada e vendida por empresas do grupo Silva Gordo, através de um empreendimento imobiliário chamado “Terras do Engenho”, restando na época, mediante acordo com a Prefeitura, apenas o local onde está implantado o Engenho Central.

Hoje, o Engenho Central juntamente com o Parque do Mirante, ambos as margens do rio Piracicaba, tornaram o ponto turístico de maior procura e exercem grande importância na economia turística da cidade, pois o visitante além de se encantar com o aspecto natural, ainda é cercado por atividades culturais e gastronômicas oferecidas no local. 


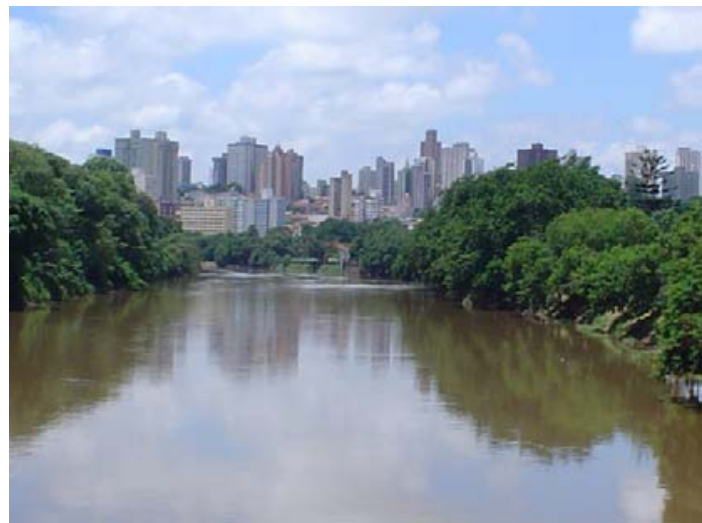

Figura 23- Rio Piracicaba

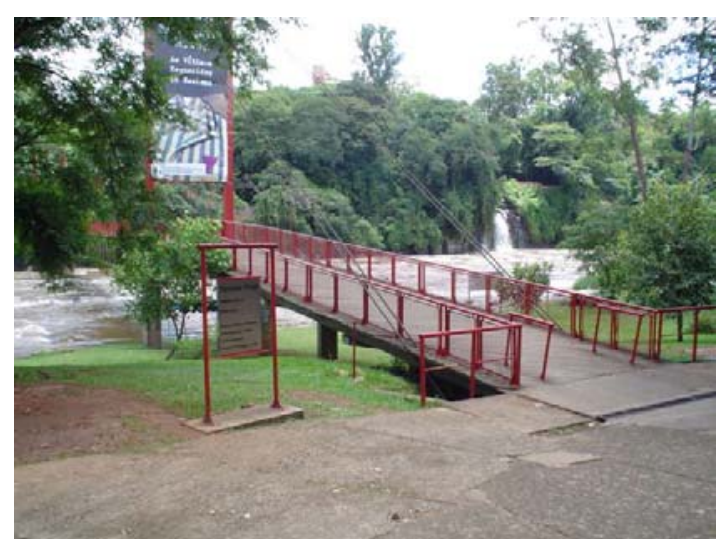

Figura 24- Parq.do Mirante/Engenho Central

\subsubsection{Parque da Esalq}

A área específica do Parque da Esalq foi inaugurada oficialmente em 1907. O projeto original e quase centenário, de estilo inglês contém, aproximadamente, 15ha que se limita, a Leste, pela estrada de Monte Alegre; ao Sul, pela Avenida Pádua Dias; a Oeste, pela alameda das Palmeiras Imperiais, entrada principal e mais antiga da Escola e, a Norte, pelo Prédio Central. Fechando o perímetro do projeto; há um prolongamento que parte do Prédio central em direção à construção utilizada hoje, após algumas reformas, pelo Serviço Social da ESALQ e que, antigamente, servia como residência a seus diretores.

Além da finalidade paisagística do parque da Esalq, outro objetivo foi o se constituir uma área rica e diversificada de coleção de plantas, com fins didáticos e científicos.

Assim, entre os muitos exemplares de espécies nativas, há uma coleção de ipês que, a todo final de inverno, colore o Parque de rosa, amarelo e branco. Existem sapucaias e oitis e a cássia ferrugem. Outras possuem frutos curiosos, como jequitibás, cedros e abricó-de-macaco. Existem muitas palmeiras e nossa famosa árvore símbolo, o pau-brasil.

O Parque da Esalq é um local bastante procurado pela população local, sobretudo nos finais de semana, quando as famílias encontram no espaço verde do 
gramado do parque o refrigério semanal e o lazer saudável, mas o lugar também tem sido procurado por turistas que se maravilham com a beleza natural e a paz oferecida.

Além do aspecto revigorador do stress humano, a área do parque da Esalq também exerce influência benéfica no aspecto ambiental urbano da cidade, proporcionando diminuição no aquecimento microclimático, ocasionado na área central, causado pelo acúmulo de áreas impermeabilizadas e aglomeração de poluentes de carros e fábricas. Ainda retém a poeira e possibilita a reoxigenação do ar.

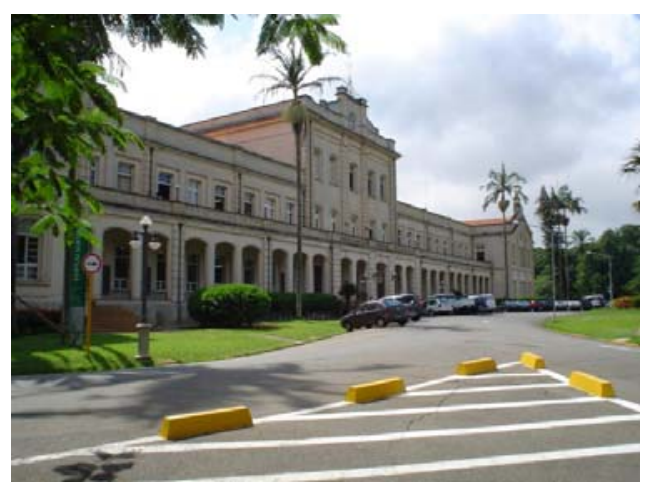

Figura 25- Prédio Centra/Parque da Esalq

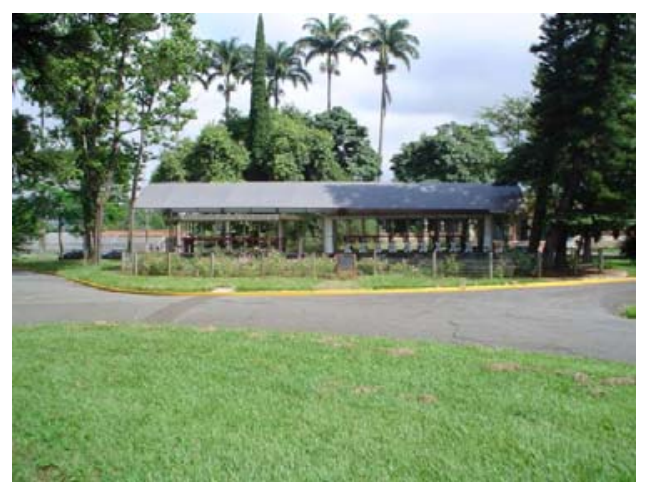

Figura 26- Bonde/Parque da Esalq 


\section{CONCLUSÕES}

Concluímos que o crescimento urbano em direção aos vetores noroeste e sudeste foram os de maiores destaques na história de expansão urbana de Piracicaba.

As áreas da cobertura vegetal dentro da área urbana consolidada e no entorno urbano sempre foram poucas, mas apresentaram até a década de 60 índices satisfatórios. Entre os anos 60 e 90 houve uma diminuição na quantidade dessas áreas. E a partir de 1995, ocorreu um pequeno aumento desses locais, com uma distribuição irregular, nas regiões sul, sudoeste e noroeste. Essas áreas em sua grande maioria são áreas de proteção permanentes (APPs), que se localizam no entorno urbano, ressaltando a necessidade de conhecer e planejar as áreas periurbanas, antes que estas se tornem áreas urbanas.

A partir da década de 80, a necessidade de se investir em locais verdes urbanos se intensificou. Esses locais não surgem normalmente. É preciso criar locais verdes em espaços vazios urbanos e como esses espaços hoje, na realidade de Piracicaba são insuficientes, a saída agora é, investir de maneira eficiente no entorno urbano, criando uma política ambiental de preservação, recuperação e reflorestamento nas áreas periurbanas, já que não há estoque de áreas naturais na área urbana consolidada.

O trabalho confirmou que o levantamento histórico da evolução urbana permite compreender a interferência que o crescimento urbano exerce sobre a quantidade, qualidade e distribuição da cobertura vegetal e na formação de áreas ambientais urbanas. 


\section{REFERÊNCIAS BIBLIOGRÁFICAS}

AMADOR, I.M. Manifestações sociais e econômicas conjugadas com as condições físico-ambientais determinam a paisagem urbana; estudo de caso: São Carlos - SP, São Paulo, 1991182 p. Tese de (Doutorado)-Faculdade de Arquitetura e Urbanismo, Universidade de São Paulo.

ANUÁRIO ESTATÍSTICO DO BRASIL. 1940. p.25, 1940.

ANUÁRIO ESTATÍSTICO DO BRASIL -1962. p.22, 1962.

ANUÁRIO ESTATÍSTICO DO BRASIL - 1978. P.23,1978.

ANUÁRIO ESTATÍSTICO DO BRASIL - 1995. P.42,1995.

ANUÁRIO ESTATÍSTICO DO BRASIL - 2002. p.22,2000.

BACELAR, T. ;BEZERRA, M. L. Experiências Recentes em Planejamento: os casos das Associações de Municípios do Setentrião e do Oeste do Paraná. Curitiba: PARANACIDADE, 1999.p.82.

BACHA, C.J.C. As Políticas Estaduais: os casos de Minas Gerais, Rio de Janeiro, São Paulo e Paraná. Paraná: s.ed.1998.145p. (Relatório de pesquisa 30018/89-4).

BALSADI, O.V. Mudanças no meio rural e desafios para o desenvolvimento sustentável. São Paulo em Perspectiva, v.15, n.1, p.155-165, 2001.

BARROS, Z.X.; CARDOSO, L.G. Estudo fotointerpretativo das áreas de cana-deaçúcar, café e eucalipto em Botucatu-SP. Científica, v. 20, p.165-171,1992.

BARTHELMESS, H.A Zona de Piracicaba. Paraná, 1958.132 p. Tese (Doutorado)Faculdade de Filosofia, Ciências e Letras, Universidade de São Paulo.

BOLFE, S.A Expansão urbana de Santa Maria, RS: uma avaliação da adequabilidade do uso do solo. São Paulo, 1997. p. 142. Dissertação de (Mestrado)- Faculdade de Arquitetura e Urbanismo, Universidade de São Paulo. 
CAVALHEIRO, F. Urbanização e alterações ambientais. In: TAUK, S. M. Análise ambiental: uma visão multidisciplinar. 2.ed. São Paulo: Editora da Universidade Estadual Paulista, 1995.123p.

CASTELLS, Manuel. La question urbaine. Paris: Ed. François maspero; 1973. p. 78.

DUARTE, L.N.R.O processo de urbanização de Piracicaba - Estudos dos planos diretores - 1971-1991. Campinas,2003. 169p. Dissertação de (Mestrado) Faculdade de Arquitetura e Urbanismo, Pontifica Universidade Católica de Campinas.

DWYER, J.F.; NOWAK, D.J.; NOBLE, M.H.; et al. Assessing our nation's urban forests: connecting people with ecosystems-in the $21^{\text {st }}$ century. Portland, OR: USDA Forest Service, 2000. 117p. (General Technical Report PNW-490).

ELIAS, B. Chácara Nazareth - desde o Império, encantamento e poder. Memorial de Piracicaba, Jul.,n. 15, p. 335 - 338, 2003.

FIORIO, P.R. Cronologia e impacto ambiental do uso da terra na microbacia hidrográfica do Ceveiro, em Piracicaba, SP. Pesquisa Agropecuária Brasileira, v.35, n.4, p.671-679, 2000.

GRAZIANO DA SILVA, J. O novo rural brasileiro. Nova Economia. v. 7, n.1, p.43-81, 1997.

GROSTEIN, M.D. Metrópole e expansão urbana: a persistência de processos insustentáveis. São Paulo em Perspectiva, v.15, n.1, p.13-19, 2001.

GROSTEIN, M.D. Metrópole e expansão urbana: a persistência de processos insustentáveis. São Paulo em Perspectiva, v. 15, n. 1, p. 13-19, 2001.

CUZZO, P. Estudos dos espaços livres de uso público da cidade de Ribeirão Preto/SP, com detalhamento da cobertura vegetal e áreas verdes públicas de dois setores urbanos. Rio Claro, 1999. 125p. Dissertação de (Mestrado) -Instituto de geociências Exatas da Universidade Estadual Paulista de “Júlio de Mesquita Filho”.

CUZZO, P. Alterações ambientais em áreas urbanas, planejamento e legislação ambiental. In: SEMINÁRIO LATINO-AMERICANO DE PLANEJAMENTO URBANO I; Campo Grande/MS,1993. Anais Campo Grande: Universidade Federal de Mato Grosso do sul, 1993. p. 82. 
KUBRUSLY, V.S. Gestão sócio-ambiental urbana e o geoprocessamento como apoio para análise do território: o caso da bacia hidrográfica do Guarapiranga. São Paulo. 2000. 147p. Tese de (Doutorado)-Faculdade de Filosofia Ciencias Humanas, Universidade de São Paulo.

LEÃO, R.M. Piracicaba passado e presente. Piracicaba: Prefeitura Municipal de Piracicaba, 1988. 83 p.

LIMA, C.R. Urbanização e intervenções no meio físico na borda da bacia sedimentar de São Paulo: uma abordagem geomorfológica. São Paulo. 1990. 105 p. Dissertação de (Mestrado)- Faculdade de Filosofia Ciencias Humanas, Universidade de São Paulo.

LIMA, A.M.L.P. Áreas verdes: muito além do conceito polêmico. Seminários do Curso de pós-graduação em solos e nutrição de plantas, ESALQ, Piracicaba: ESALQ, $1989.52 \mathrm{p}$.

LOJKINE, J. O Estado capitalista e a questão urbana. São Paulo: Editora Martins Fontes, 1981. 72p.

MARTINES, P.R. Metodologia para a análise espaço-temporal da expansão urbana através do geoprocessamento: uma aplicação para a cidade de Piracicaba-SP (1822-1996).Rio Claro. IGCE;UNESP 1998. 83p. (Relatório final de estágio de iniciação científica).

MEDEIROS, E.B. O lazer no planejamento urbano. Rio de Janeiro: FGV-RJ,1975. 72p.

MEMORIAL DE PIRACICABA. Em busca do tempo futuro. Piracicaba: Editora Artes Gráficas, 2003. 76 p.

MILANO, M.S. A cidade, os aspectos e a vegetação In: CONGRESSO BRASILEIRO SOBRE ARBORIZAÇÃO URBANA, 1., Curitiba, 1992. Anais. Curitiba: FUPEF;UFPR, 1992, p.3-14.

MILANO, M.S. Avaliação qualiquantitativa e manejo da arborização urbana: exemplo de Maringá - PR. Curitiba, 1988. 63p. Tese de (Doutorado)-Fundação de Pesquisa Florestais do Paraná,Univesidade Federal do Paraná 
MILANO, M.S. Planejamento da arborização urbana: relação entre áreas verdes e ruas arborizadas. In: ENCONTRO NACIONAL SOBRE ARBORIZAÇÃO URBANA, 3., Curitiba, 1990. Anais. Curitiba: FUPEF, 1990. p.61.

MORENO, J. Análise da organização e dinâmica das condições ambientais e urbanas face a uma nova ordem econômica: Piracicaba e seu entorno. EESC/USP, São Carlos. 2000. 233p. Tese de (Doutorado)-Escola de Engenharia de São Carlos, Universidade de São Paulo.

OREA, D.G. El médio físico y la planificacion. I. Madrid: Centro Internacional de Formación en Ciências Ambientales, 1978. 72 p.

PERECIN, M.T.G. Canoas e monjolos, engenhos e navios. Revista do Instituto Histórico e Geográfico de Piracicaba, v. 2, n.2, p.3-12, 1992.

PERECIN, M.T.G Piracicaba nos Anais dos Morgados de Mateus. Revista do Instituto Histórico e Geográfico de Piracicaba, v.4,n.4,p.7-451, 997.

PETRONE, M.T.S. A lavoura canavieira em São Paulo. São Paulo: Difusão Européia do Livro, 1968. 112p.

POMPERMAYER, R. M.T. Espaço urbano de Piracicaba: Sua ocupação e evolução,1998. (Relatório final apresentado à FAPESP).

PREFEITURA MUNICIPAL DE PIRACICABA. Piracicaba: passado e presente. Piracicaba: Editora Artes Gráficas ,1988 p.17-32.

PREFEITURA MUNICIPAL DE PIRACICABA. Plano diretor de desenvolvimento de Piracicaba 1991. Piracicaba: Secretaria do Planejamento; SEMUPLAN. 1991. p.82.

RANZANI, G. Subsídios à geografia de Piracicaba. Piracicaba: Institutos Históricos e Geográficos de Piracicaba, 1996. 26p.

SAMPAIO, S.S. Geografia industrial de piracicaba: Um exemplo de interação indústria /agricultura. Rio Claro Tese de (Doutorado)-Instituo de Geociências e Ciencias Exatas, Universidade Estadual Paulista “Julio de Mesquita Filho”.

SCARLATO, F.C. População e urbanização brasileira In: ROSS, J.L.S. (org.) Geografia do Brasil. São Paulo: EDUSP, 1996 p.381-463. 
SILVA, J.A. Direito ambiental constitucional. São Paulo: Malheiros Editores, 1994. 243 p.

SILVA, J.A. Direto urbanístico brasileiro. São Paulo: Ed. Revista dos Tribunais, 1981. $617 \mathrm{p}$.

SILVA, L.O. Subsídios para formulação de uma política para áreas verdes no Município de São Paulo - SEMPLA. In: São Paulo: Prefeitura do Município de São Paulo Questão Ambiental Urbana - Cidade de São Paulo, PMSP, 1993. p.72.

SIMÕES, S.J.C. Variabilidade, fragilidade e dinâmica da paisagem em área de transição urbano-rural. São Paulo, 1996. 205 p. (Tese de Doutorado)-Faculdde de Filosofia e Ciências Humanas. Universidade de São Paulo.

SOMEKH, N. A cidade vertical e o urbanismo modernizador em São Paulo. São Paulo: Studio Nobel, 1997. 60 p.

SPAROVEK, G.; SCHNUG, E. Temporal erosion-induced soil degradation and yield loss. Soil Science Society of America Journal, v. 65, n. 5, p. 1479-1485, 2001.

STACCIARINI, J.H.R. Os catalanos e a questão ambiental. A voz do Sudeste,n.7, p.14, jul.1989.

VITTI, G. Manual de história piracicabana. Jornal de Piracicaba, Piracicaba,10 Maio, 1966. p.16. 